\title{
Application of Nanofluids in Thermal Performance Enhancement of Parabolic Trough Solar Collector: State-of-the-Art
}

\author{
Hamed Olia ${ }^{1}$, Mohammadamin Torabi ${ }^{2}{ }^{-}$, Mehdi Bahiraei ${ }^{3}$, Mohammad Hossein Ahmadi ${ }^{4}$, \\ Marjan Goodarzi ${ }^{5}$ (D) and Mohammad Reza Safaei $6,7, *$ \\ 1 Department of Mechanical Engineering, Colorado School of Mines, Golden, CO 80401, USA; \\ holia@mines.edu \\ 2 Department of Civil and Environmental Engineering, Idaho State University, Pocatello, ID 83209, USA; \\ toramoha@isu.edu \\ 3 Department of Mechanical Engineering, Kermanshah University of Technology, Kermanshah, Iran; \\ m.bahiraei@kut.ac.ir \\ 4 Faculty of Mechanical Engineering, Shahrood University of Technology, Shahrood, Iran; \\ mhosein.ahmadi@shahroodut.ac.ir \\ 5 Department of Mechanical Engineering, Lamar University, Beaumont, TX, USA; mgoodarzi@lamar.edu \\ 6 Division of Computational Physics, Institute for Computational Science, Ton Duc Thang University, \\ Ho Chi Minh City, Vietnam; cfd_safaei@tdtu.edu.vn \\ 7 Faculty of Electrical and Electronics Engineering, Ton Duc Thang University, Ho Chi Minh City, Vietnam \\ * Correspondence: cfd_safaei@tdtu.edu.vn; Tel.: +1-502-657-9981
}

Received: 31 December 2018; Accepted: 25 January 2019; Published: 29 January 2019

check for updates

\begin{abstract}
The present review paper aims to document the latest developments on the applications of nanofluids as working fluid in parabolic trough collectors (PTCs). The influence of many factors such as nanoparticles and base fluid type as well as volume fraction and size of nanoparticles on the performance of PTCs has been investigated. The reviewed studies were mainly categorized into three different types of experimental, modeling (semi-analytical), and computational fluid dynamics (CFD). The main focus was to evaluate the effect of nanofluids on thermal efficiency, entropy generation, heat transfer coefficient enhancement, as well as pressure drop in PTCs. It was revealed that nanofluids not only enhance (in most of the cases) the thermal efficiency, convection heat transfer coefficient, and exergy efficiency of the system but also can decrease the entropy generation of the system. The only drawback in application of nanofluids in PTCs was found to be pressure drop increase that can be controlled by optimization in nanoparticles volume fraction and mass flow rate.
\end{abstract}

Keywords: parabolic trough solar collectors; nanofluid; thermodynamic performance; entropy generation; exergy analysis

\section{Introduction}

Nowadays, one of the vital global challenges is the increase of greenhouse gases content in the Earth's atmosphere. The mean content of $\mathrm{CO}_{2}$ in the Earth's atmosphere has increased from 390 ppm in 2011 [1] to roughly 410.19 ppm up to 2018 [2] which has resulted in increasing the Earth's atmosphere temperature. This alarming increase in both $\mathrm{CO}_{2}$ content and its corresponding increase in temperature along with the finite resources of oil and gas have forced human beings to face a challenge as well as a new opportunity of finding a different source of energy; renewable energy. There are many types of renewable energy known so far. Renewable energy can be categorized into six distinct resources, including hydropower, modern biomass, geothermal, solar, wind, and wave and tide [3]. 
Solar energy has many advantages over other types of renewable energy. Most importantly, solar energy, compared to other types of renewable energy resources, is considered the greatest resource, as the energy provided to Earth by the Sun in an hour can be more than the whole amount of the energy consumed by human beings in a year [4]. However, solar energy is currently providing rather a small portion of the total energy supply; this energy can be the most useful energy in the future.

Solar energy can be separated to two major types, solar photovoltaic, which directly convert the Sun's light to electricity, and solar thermal collectors which concentrates the Sun's light to generate heat and use the heat to run heat engines [5].

The conversion efficiency of Photovoltaic (PV)cells are typically in the range of $10-20 \%$, as much as the radiation heat up the cells, the efficiency goes down [5], which by considering the price is not affordable. However, besides its cost, one cannot deny that solar energy in some cases is the only option for remote areas and this advantage makes it an asset.

Another way to harness solar energy is the use of solar thermal collectors. The direct absorption solar collector (DASC) was the pioneer in this type of solar collectors introduced in the 1970s, instead of simple flat plate type collectors [6]. Solar thermal collectors work based on concentrating and absorbing the sunlight, converting to heat, and transferring this heat to a working fluid which can be liquid or gas. Working fluids can be water, oil, molten salt, air nitrogen, or helium flowing through the collectors [7]. Enhancing heat transfer and thermal conductivity through these working fluids can cause increasing efficiency. In recent years, research along this issue got popularized among scientists. It was suggested to add solid nanoparticles to common working fluid to enhance the effective thermal conduction. Using nanoparticles instead of particles with sizes in order of micrometer diminishes the issues associated with erosion and corrosion of components as well as the sedimentation and clogging of particles [8]. This mixture considerably increased the heat transfer rate and the suspension called nanofluid [9-11]. Nanofluid, which consists of particles with a dimension less than $100 \mathrm{~nm}$ dispersed in a base fluid, can be defined as suspensions of NPs. This nanofluid is able to enhance conductivity and heat transfer coefficient of working fluid. Choi et al. [9], by introducing and discussing a new idea on using nanoparticles, became pioneers in efficiency enhancement of working fluid in thermal systems. Their results revealed the benefits of using copper-based nanofluid. Additionally, they discussed the theoretical aspect of the nanofluid's thermal conductivity and the potential impacts of nanofluid in improving heat transfer. Over a decade ago, using nanofluid as the working fluid of collectors gained a great devotion as a revolution in the heat transfer [12].

The main focus of the paper is divided into four distinct sections. First, parabolic trough solar collectors are discussed in general in terms of different types, components, and application. Next, the application of nanofluids is discussed in different parts of solar energy sectors. Afterward, the application of nanofluids is investigated thoroughly in parabolic trough collectors (PTC). This section reviews the studies conducted on PTC into two different sections of experimental and numerical investigations. In conclusion, the summary of the review is presented and the advantages and disadvantages of nanofluids application in PTC is summarized based on the conducted review. Finally, the challenges of the nanofluids application in PTC is discussed.

\section{Parabolic Trough Solar Collectors}

These days, different types of solar collectors are widely used to harvest solar energy. Solar collectors can be separated into two essential types including stationary and tracking concentrating [13]. Stationary or non-tracking collectors include flat plate solar collectors (FPT) [14], evacuated tube collectors (ETC) [15], compound parabolic collector and bowl collector [16], which are mostly used for heating liquids. Other types of solar collectors are based on heating air, including the through-pass air collector [17] and unglazed transpired solar collector [18]. These types of collectors work based on capturing radiation from the sun and transferring thermal energy to air via conduction heat transfer. Sun tracking concentrating collectors are other types of solar thermal collectors, which are able to track the sun by either one or two axes and concentrate the sunlight on the focal point (or line). One 
axisincludes the parabolic trough [19], cylindrical trough, and linear Fresnel collector [20], and two axes includes parabolic dish [21], parabolic tower [19], and circular Fresnel [22]. Figure 1 shows the classification of solar collectors.

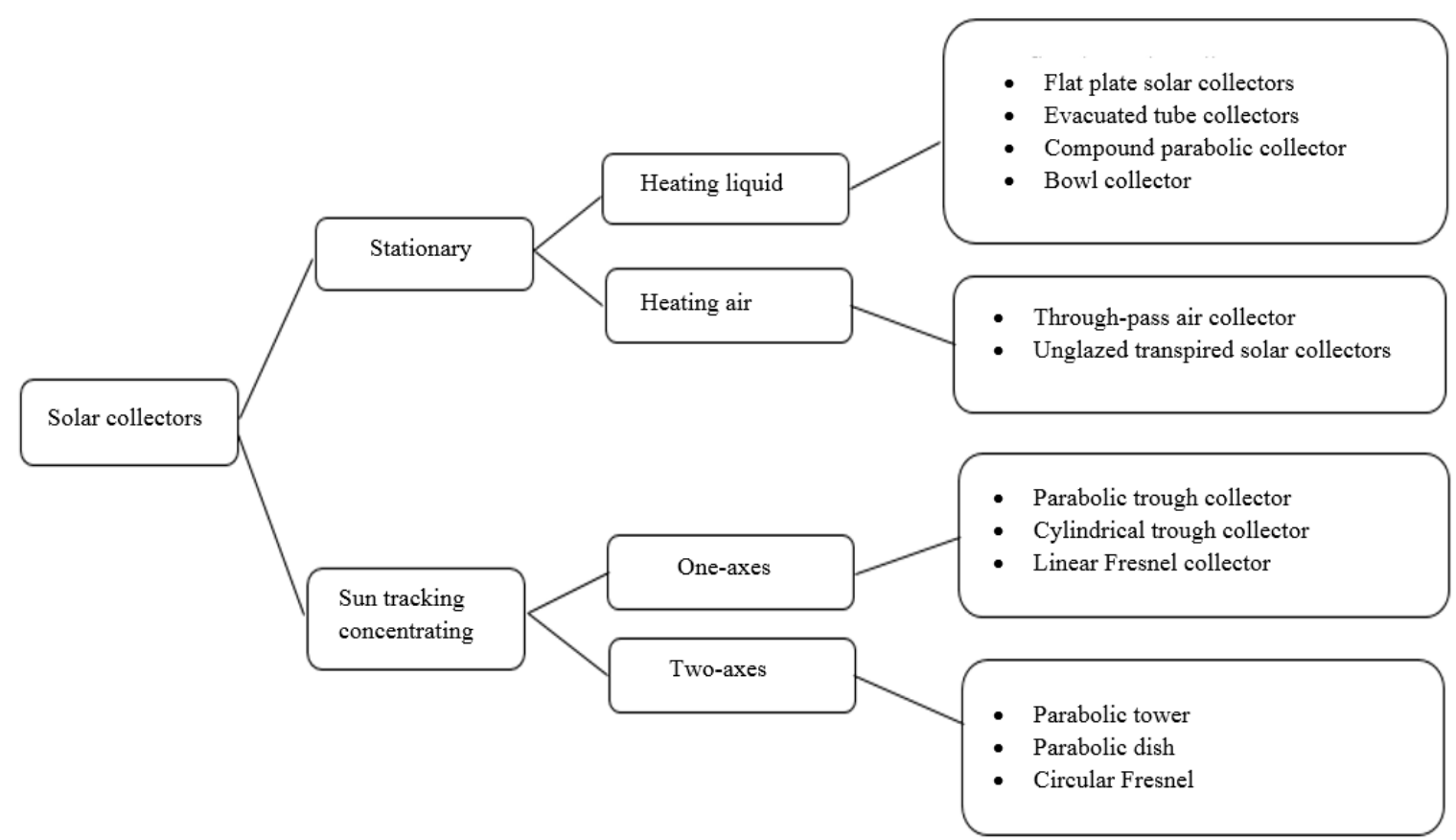

Figure 1. Solar collectors' classification.

Parabolic trough solar collectors consist of a parabolic reflector. This parabolic sheet can be made by bending a sheet to parabolic shape. The sheet should be highly reflective and be constructed as a long parabolic reflecting mirror. In this type, the solar collector should be pointed directly into the Sun, and since the solar radiation is parallel, all light waves can reflect on focal from all parts of the trough-shaped as shown in Figure 2. This consequently causes the central pipe to heat up.

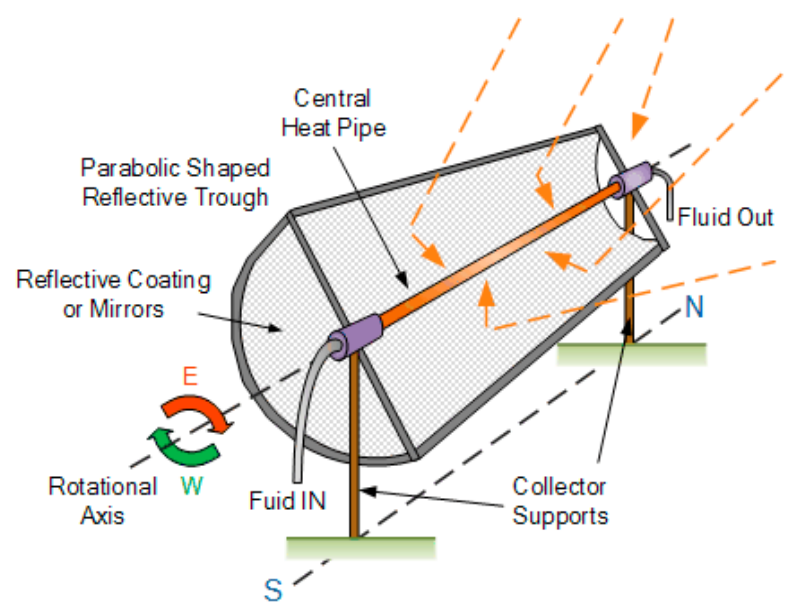

Figure 2. General conceptual form of a parabolic trough collector (PTC) [23].

The parabolic trough solar collectors consist of different parts:

- $\quad$ Parabolic reflectors

- $\quad$ Receiver tube

- $\quad$ Support structure

- $\quad$ Tracking system 
The receiver tube which is located at the focal line of parabolic trough reflective surface (Figure 3) can transfer the absorbed solar energy to the fluid flowing inside. The tube usually consists of two layers to make it more efficient. An outer layer is made out of glass which is transparent and anti-reflecting to solar radiation and can reduce convection and radiation losses and maintain strength and transmittance under high temperatures [24], as well as an inner layer of copper or selective blackened nickel which, inside of it, circulates the heat transfer fluid [25].

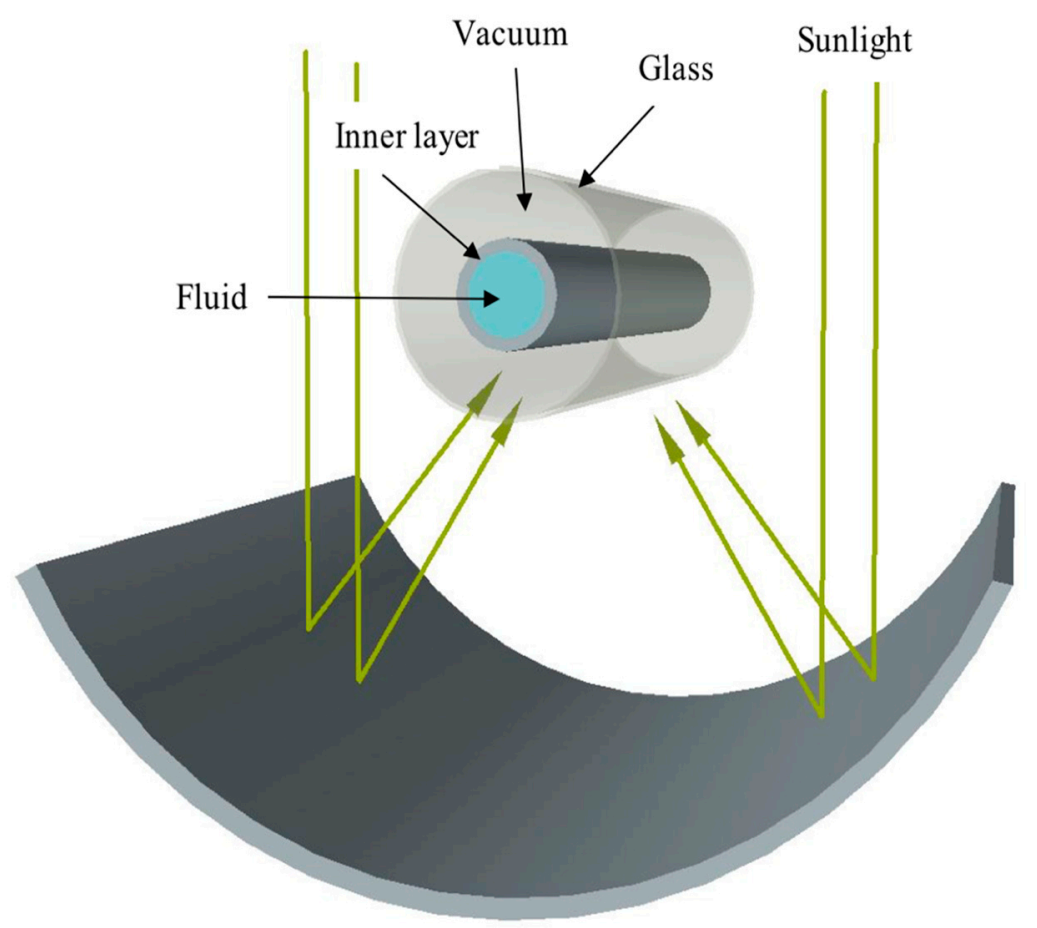

Figure 3. Detail of parabolic trough solar collector.

Coating of the inner layer makes it capable of reducing thermal radiation losses by absorbing the short length solar radiation and also low emissivity for long wave energy spectrum [24].

The device also includes one-axis solar tracking to align the trough with sunlight and make sure the maximum amount of radiation will be reflected on the focal line [26]. Parabolic troughs are rotated to track the Sun as it moves across the sky each day from morning to night. This is one of the crucial sections which can increase the efficiency and maximize the solar heat gain.

The critical section of parabolic trough solar collector is the heat transfer fluid flowing inside the tube, which is usually a mixture of water or thermal oil and other additives like nanofluids which enhance thermal conduction. The fluid is pumped through the tube and absorbs the solar heat reaching temperatures of over $200{ }^{\circ} \mathrm{C}$. The hot water is then directed to a heat exchanger where it can heat a storage tank for different applications.

As mentioned above, PTC is used in large scales as solar concentrating technology. Nanofluid-based concentrating parabolic solar collectors (NCPSC) provide better energy absorption and conductive heat transfer compared with conventional parabolic trough concentrators [27]. Recently, the use of nanofluids as the working fluid in parabolic trough solar collectors (PTC) is getting more common.

\section{Nanofluids Usage in Solar Energy}

Working fluid is one of the most essential parts in solar conductors which play a significant role in heat transfer of PTC. It has been numerous attempts toward enhancing the thermal conductivity of working fluid from the beginning of solar energy usage. Khullar et al. [28] investigated the application of nanofluids in concentrating parabolic trough solar collector (CPT). Otanicar et al. [29] conducted 
experimental research on the influence of different nanofluids used as working fluid on the efficiency of solar thermal collectors. The studied nanoparticles were graphite, two different silver nanoparticles with different size, and carbon nanotubes. It was shown that the efficiency with adding $20 \mathrm{~nm}$ silver particle improve roughly by $5 \%$ compared with the conventional working fluids. They investigated the effect of graphite, copper, aluminum, and silver nanoparticles (at low concentration of $0.001 \mathrm{vol}$. \%) dispersion into Therminol VP-1 on increasing the efficiency of power tower solar collectors. They showed that using the nanofluid in the receiver can lead to a theoretical increase of $5-10 \%$ in efficiency. However, they believed that the usage of nanofluids in trough solar collectors or dish solar collectors are not appropriate at that time and requires further improvement. A mathematical model is proposed by Khullar et al. [30] in order to investigate the effect of nanofluid concentration in NCPSC. They found that the application of nanofluid in parabolic through the collector (PTC) can enhance their thermal efficiency. Saidur et al. [31] studied the volume fraction and size effect of nanoparticles in direct solar collectors. It turned out that the extinction coefficient is directly proportional to the weight percentage of nanoparticles. However, the particle size has an insignificant effect on optical characteristics of nanofluids. They also showed at $1.0 \%$ volume fraction, a good improvement is resulted in solar absorption and the nanofluid is almost not transparent to light wave.

The mass fraction and mass flow rate influence of $\mathrm{Al}_{2} \mathrm{O}_{3}$ nanofluid as working fluid on the direct absorption type solar collector studied experimentally by Verma et al. [32]. It was shown that at the particular wt $\%$ of approximately $5 \%$, the maximum efficiency enhancement of $5 \%$ could be achieved. Parvin et al. [33] investigated the effect of $\mathrm{Cu}$-water nanofluid volume fraction and Reynolds number on heat transfer performance of a direct absorption solar collector. The results showed that the forced convection heat transfer performance was increased with both increasing Reynolds number and volumetric concentration. More specifically, at highest nanoparticle volume fraction and the largest Reynolds number, the best performance of heat transfer is achieved.

\section{Application of Nanofluid in PTC}

By increasing use of nanofluids, many investigators have been interested in the application of nanofluids in solar collectors. There are many researchers that conducted reviews on the application of nanofluids in solar collectors. Verma et al. [34] conducted a review on the progressive application of nanofluid in solar collectors, in which thermophysical properties of nanofluids and performance evaluation of different types of solar collectors using nanofluid were discussed. Nagarajan et al. [35] also summarized the application of nanofluids in different solar collector systems. More specifically, the thermophysical properties, different types of nanofluids, and the history of the solar energy and its diverse applications were discussed. Sandeep et al. [36] reviewed different methods used to enhance heat transfer in PTCs, specifically the use of nanofluids in heat transfer enhancement. Bellos et al. [37-39] provided a review on nanofluids application in solar collectors, mostly concerning their applications on thermal efficiency enhancement. However, there is no comprehensive literature review on nanofluids application in PTCs.

There are many ways by which the studies concerning the application of nanofluids in PTC can be classified:

The first classification can be done on types of nanoparticles used in studies. The nanoparticle can be categorized into two main sections (Bellos et al. [39]):

1. Metallic nanoparticles such as $\mathrm{Fe}, \mathrm{Cu}, \mathrm{Zn}, \mathrm{Al}, \mathrm{Au}$.

2. Non-metallic nanoparticles such as $\mathrm{SiO}_{2}, \mathrm{TiO}_{2}, \mathrm{Fe}_{2} \mathrm{O}_{3}, \mathrm{ZnO}, \mathrm{CeO}_{2}$, multiwall carbon nanotubes (MWCNT), carbon nanotubes (CNT)

As it can be seen from Figure $4, \mathrm{Al}_{2} \mathrm{O}_{3}$ is the most applicable nanoparticle among researchers since $41 \%$ of studies use it in the studies, followed by $\mathrm{CuO}, \mathrm{TiO}_{2}$, etc. Both metallic and non-metallic nanoparticles can be dispersed into the base fluid at a different volumetric concentration ranging from $0.01-6 \%[37,40,41]$ or weight percentage ranging from $0.1-20 \mathrm{wt} \%[42]$. 


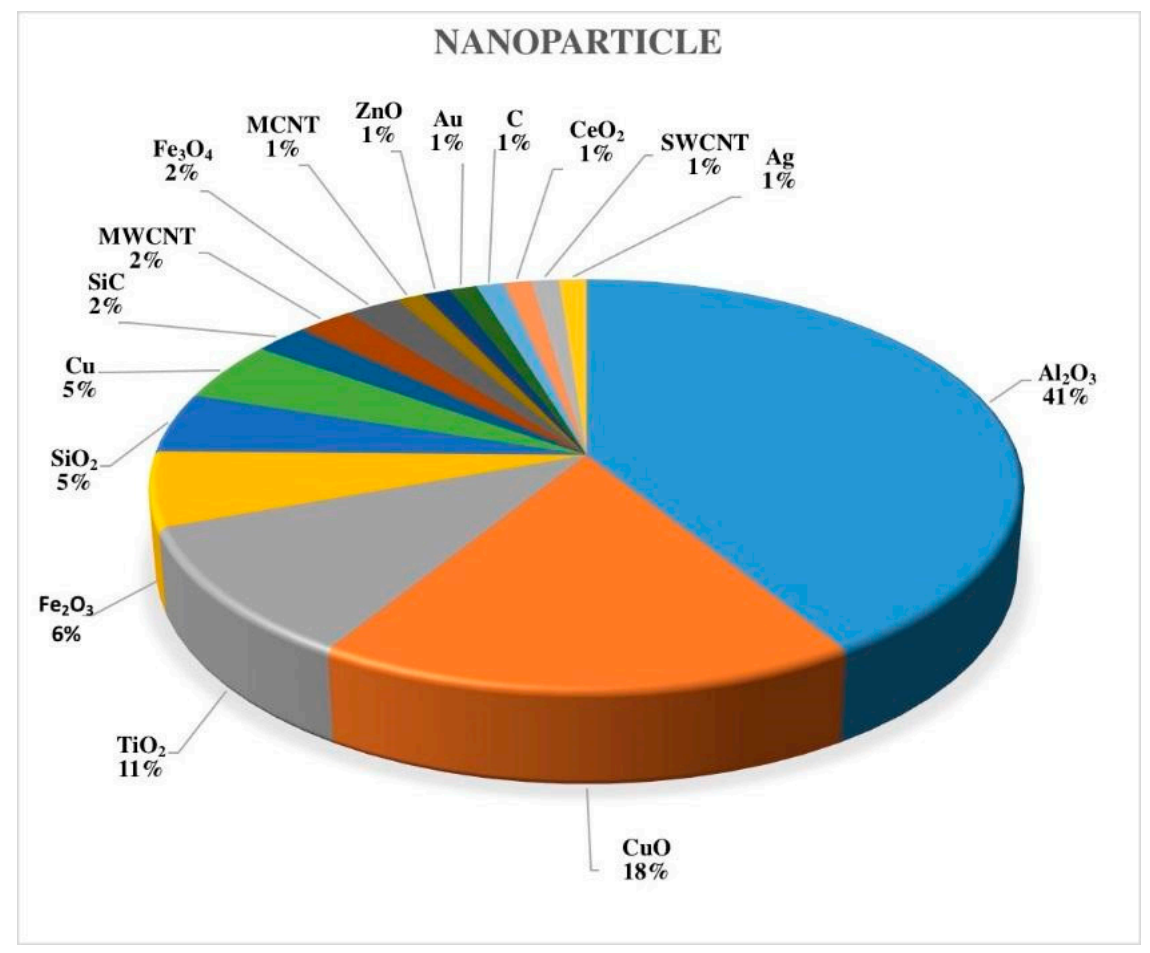

Figure 4. Share of different nanoparticles on the studies concerning PTC enhancement using nanofluids.

Additionally, the other way to study nanofluids is to talk about different types of base fluids in which the nanoparticles are dispersed in. There are mostly four significant types of base fluid used so far:

1. Water

2. Oils (such as Synthetic oils, thermal oils, Therminol-VP-1, Dowtherm-A, etc.)

3. Ethylene glycol (EG)

4. Molten salts (such as $60 \% \mathrm{NaNO}_{3}-40 \% \mathrm{KNO}_{3}$ )

Another way to categorize the studies is to classify them by type of studies:

1. Experimental studies

2. Numerical investigations

Nanoparticles used in the thermal enhancement of PTC have different diameter sizes which range from 4-100 $\mathrm{nm}[43,44]$. As stated earlier, thermophysical properties of nanofluids are of high importance. There are numerous studies trying to review the equations stating these parameters in terms of temperature, nanoparticle size, concentration, etc. A comprehensive review of these thermophysical properties is given in [34,35].

The main reason encouraging investigators to use nanofluids (instead of base fluids) are their enhanced thermal properties. Thermal efficiency and convective heat transfer are two main factors that are required to be enhanced to give a better performance in PTC. Also, nanofluids have a higher thermal conductivity, density, and viscosity while lower specific heat capacity is comparing to the base fluid. It should be noted that higher viscosity is actually a drawback in the nanofluid application as it increases friction factor and hence causes pressure drop along the receiver tube of the PTC which finally increases the pumping demand of the nanofluid in PTC [39].

Thermal enhancement of PTCs has been in the canon of interest recently. The enhancement can be done by two methods: geometrical modification and application of nanofluids instead of common base fluids in PTC [39]. 
Among all types of studies can be done on the application of nanofluid in PTC, the main focus of present work is about reviewing different studies investigating thermal, thermodynamical, and hydraulic enhancement caused by the nanofluid application in PTCs.

\subsection{Experimental Studies}

Among different studies about enhancing PTC efficiency by nanofluids, 30\% of research studies have been carried out experimentally. The effects of different nanofluids with different nanomaterials percentage have been investigated to find the efficient one. It was reported by most of them that the application of nanofluid in PTC leads to higher thermal efficiency comparing to the base fluid. In this regards, Sharma et al. [41] set up an experimental setting and conducted a study about the effect of two different nanofluids of $\mathrm{Al}_{2} \mathrm{O}_{3} /$ water and $\mathrm{CuO} /$ water at 0.01 and 0.05 vol. \% on PTC thermal performance and compared the results with water as working fluid. The results indicated that $\mathrm{CuO}$ /water nanofluid could cause the highest thermal enhancement; followed by $\mathrm{Al}_{2} \mathrm{O}_{3} /$ water nanofluid and water, itself. More specifically, they found that using 0.05 vol. $\%$ of $\mathrm{CuO}$ and $\mathrm{Al}_{2} \mathrm{O}_{3}$ have the maximum overall thermal efficiency of $15.25 \%$ at a maximum flow rate. Whereas this value for $\mathrm{Al}_{2} \mathrm{O}_{3} /$ water nanofluid and water itself was $12.39 \%$ and $10.58 \%$, respectively. This means using $\mathrm{CuO} /$ water nanofluid led to approximately $44 \%$ increase in efficiency, compared with water.

Another experimental study carried out on the effect of MWCNT/mineral oil (with 0.2 and $0.3 \mathrm{wt} \%$ ) on the performance of PTC by Kasaeian et al. [45]. Authors claimed that using $0.3 \% \mathrm{wt} \%$ of MWCNT enhances the thermal efficiency of the PTC between 5-7\%.

Siva Reddy et al. [46] examined $\mathrm{Al}_{2} \mathrm{O}_{3}$ /water nanofluid to investigate its effect on the thermal efficiency of PTC. They used up to 0.06 vol. $\%$ of $\mathrm{Al}_{2} \mathrm{O}_{3}$. They reported a maximum efficiency enhancement due to the nanofluid application of $28.95 \%$.

Kandwal et al. [40] studied two nanofluids, $\mathrm{CuO} /$ water and $\mathrm{CuO} /$ ethylene glycol to experimentally investigate their effect on PTC performance at different volumetric concentrations $(0.01$, 0.05 , and 0.1 vol. \%) and flow rates. They found that the maximum thermal efficiency can be attained by application of different nanofluids are $11.01 \%, 8.03 \%, 7.46 \%$, and $6.04 \%$ for $\mathrm{CuO} /$ water, $\mathrm{CuO} /$ ethylene glycol, water, and ethylene glycol at $160 \mathrm{~L} / \mathrm{h}$. This means that there was an approximately $82 \%$ thermal efficiency increase when using $\mathrm{CuO} /$ water nanofluid comparing with ethylene glycol.

An experimental investigation was conducted by Chaudhari et al. [47] on the effect of $1 \%$ volumetric concentration of $\mathrm{Al}_{2} \mathrm{O}_{3}$ in $\mathrm{Al}_{2} \mathrm{O}_{3}$ /water nanofluid in the thermal characteristic enhancement of PTC. The results showed that the application of nanofluid could enhance the heat transfer coefficient and thermal efficiency by $32 \%$ and $7 \%$, respectively, comparing to the base fluid (water). They also reported an approximately maximum increase in Nusselt number of $32 \%$.

An interesting experimental study was done by Coccia et al. [42], where they examined many different nanoparticles $\left(\mathrm{Fe}_{2} \mathrm{O}_{3}, \mathrm{SiO}_{2}, \mathrm{TiO}_{2}, \mathrm{ZnO}, \mathrm{Al}_{2} \mathrm{O}_{3}\right.$, and $\mathrm{Au}$ ) with different weight fraction ranging from $0.1-35 \%$ with water as the base fluid. They showed that using these different nanofluids had almost no effect on the thermal efficiency of the PTC as well as no significant change in pressure drop. The only relatively significant enhancement was observed when the convection heat transfer increased by approximately $50 \%$ when $\mathrm{Au} /$ water nanofluid with $0.01 \%$ volumetric concentration of $\mathrm{Au}$ was applied with increasing the temperature (from $40-80^{\circ} \mathrm{C}$ ).

An experimental and numerical study was conducted to study the effect of $\mathrm{CuO} /$ water nanofluid on thermal efficiency and temperature distribution in direct absorption parabolic trough collectors for a different range of volume fractions by Menbari et al. [48]. The numerical and experimental results were in good agreement with each other. The results were shown that the thermal efficiency of the collector increases by $18 \%$ to $52 \%$, when using $0.002-0.008$ vol. $\%$ CuO nanoparticles, compared to the base fluid case.

Subramani et al. [49] experimentally investigated the effect of $\mathrm{Al}_{2} \mathrm{O}_{3}$ /water nanofluid on thermal behavior of the PTC at $0.05-0.5 \mathrm{vol} \%$ of $\mathrm{Al}_{2} \mathrm{O}_{3}$. They concluded that the thermal efficiency could be enhanced by $8.54 \%$ if the maximum volume fraction of $0.5 \%$ was applied. 
Kasaeian et al. [44] conducted an experiment in which he used a different base flow, ethylene glycol (EG) and dispersed MWCNT and $\mathrm{SiO}_{2}$ in it up to $0.3 \%$ volume fraction. They reported that MWCNT/ethylene glycol is the most efficient fluid in term of higher thermal efficiency. The thermal enhancement of $30.4 \%$ and $14 \%$ was suggested by them for MWCNT/ EG and $\mathrm{SiO}_{2}$ / EG, respectively, comparing with EG as the base fluid.

Sekhar et al. [50] examined the effect of $\mathrm{CeO}_{2}, \mathrm{Al}_{2} \mathrm{O}_{3}$, and $\mathrm{TiO}_{2}$ with water as a base flow on the performance of PTC. They used a variety of volume fraction ranging from 0.5 to $3 \mathrm{vol}$. \%. They found that at $3 \%$ volume fraction, $\left(\mathrm{CeO}_{2}\right) /$ water nanofluid had the highest thermal efficiency enhancement by $27 \%$, followed by alumina and titania nanofluid with $25 \%$ and $23 \%$ enhancement, respectively.

Rehan et al. [51] experimentally studied the effect of $\mathrm{Al}_{2} \mathrm{O}_{3}$ and $\mathrm{Fe}_{2} \mathrm{O}_{3}$ nanoparticle dispersed in water with different weight fraction ranging from $0.2-0.3 \%$ and flow rates $(1-2 \mathrm{~L} / \mathrm{min})$ on the thermal efficiency of the PTC in winter. It was concluded that at $2 \mathrm{~L} / \mathrm{min}$ flow rate and $0.3 \mathrm{wt} \%, \mathrm{Al}_{2} \mathrm{O}_{3} /$ water and $\mathrm{Fe}_{2} \mathrm{O}_{3}$ /water nanofluid application enhances the thermal efficiency by $13 \%$ and $11 \%$, respectively.

Subramani et al. [52] examined the effect of $\mathrm{TiO}_{2} /$ water nanofluid at different volume fractions of $0.05-0.5 \%$ on PTC thermal performance. They reported that at $4 \mathrm{~kg} / \mathrm{min}$ mass flow rate both convection heat transfer and thermal efficiency of PTC could be enhanced by $22.76 \%$ and $8.66 \%$.

Marefati et al. [53] experimentally investigated the effect of $\mathrm{Al}_{2} \mathrm{O}_{3}, \mathrm{CuO}$, and $\mathrm{SiC}$ mixed with water at 1-5 vol. \% on the thermal and optical performance of the PTC at four different locations in Iran (Tehran, Yazd, Shiraz, and Tabriz). Shiraz was found to have the highest thermal efficiency resort to install the PTC. They also mentioned that the application of $\mathrm{CuO} /$ water nanofluid enhances the convection heat transfer by approximately $33 \%$ compared with water itself. Hence, as expected, $\mathrm{CuO} /$ water nanofluid is the best option for thermal efficiency enhancement.

Okonkwo et al. [54] selected six working fluids including supercritical $\mathrm{CO}_{2}$, Therminol VP-1, pressurized water, $\mathrm{Al}_{2} \mathrm{O}_{3}$ /Therminol VP-1, CuO/Therminol VP-1, and $\mathrm{Fe}_{3} \mathrm{O}_{4}$ /Therminol and conducted an experimental study to study their effect on the thermal efficiency of PTC. They concluded that application of pressurized water as working fluid might lead to highest efficiency enhancement at low temperatures. However, due to its application limits, it causes difficulty to use. Aside from pressurized water, $\mathrm{Al}_{2} \mathrm{O}_{3}$ /Therminol VP-1, $\mathrm{CuO} /$ Therminol VP-1, and $\mathrm{Fe}_{3} \mathrm{O}_{4} /$ Therminol application can lead to the efficiency enhancement of $0.22 \%, 0.18 \%$, and $0.15 \%$. This means that $\mathrm{Al}_{2} \mathrm{O}_{3} /$ Therminol VP-1 nanofluid is the best working fluid to achieve the highest efficiency.

Alsaady et al. [55] conducted an experimental study on Ferrofluids (magnetic nanofluid) with $0.05 \%$ volume fraction with and without magnetic field presence. They found that if a magnetic field is applied, the thermal efficiency can be enhanced up to $25 \%$ compared to conventional PTC.

De Los Rios et al. [56] investigated the effect of $\mathrm{Al} 2 \mathrm{O} 3$ / water nanofluid with $1 \%$ and $3 \%$ volumetric concentration on the thermal efficiency of PTC experimentally. The results indicated that using $3 \%$ volumetric concentration of $\mathrm{Al}_{2} \mathrm{O}_{3}$ can enhance the efficiency by approximately $28 \%$ ( $40.8 \%$ to $52.4 \%$ ) compared to water as a base flow at incident angles varying from 20-30.

Finally, Okonkwo et al. [57] conducted an experimental study on the application of green-synthesized nanofluid $\left(\mathrm{OLE}-\mathrm{TiO}_{2} /\right.$ water and $\mathrm{BH}-\mathrm{SiO}_{2} /$ water) with the maximum volume fraction of $0.05 \mathrm{vol}$. \%. It was shown that the mean thermal efficiency increased by $0.073 \%$ and $0.077 \%$ for $\mathrm{BH}-\mathrm{SiO}_{2} /$ water and $\mathrm{OLE}-\mathrm{TiO}_{2} /$ water nanofluid, respectively. Also, the heat transfer coefficient increased significantly up to $138 \%$ for $\mathrm{BH}-\mathrm{SiO}_{2}$ / water nanofluid. The authors suggested that in terms of better thermal enhancement, both nanoparticles $\left(\mathrm{OLE}-\mathrm{TiO}_{2}\right.$ and $\left.\mathrm{BH}-\mathrm{SiO}_{2}\right)$ are superior to $\mathrm{Al}_{2} \mathrm{O}_{3}$ nanoparticles. Table $\mathrm{A} 1$ at Appendix A summarizes the details and important notes about the experimental studies.

\subsection{Numerical Studies}

Numerical studies have been the researchers' most favorable tool to study the effect of nanofluids in PTC, since more than $60 \%$ of studies were done using numerical approaches. The main reason for that can be found on relatively cheaper cost comparing with an experimental study which might need higher 
cost for both system setup and material purchase. Numerical investigations include approximately $70 \%$ of studies done on the effect of nanofluid on PTC thermal, hydraulic, and thermodynamic behavior. It should be noted that ANSYS Fluent is the main program used for the numerical investigation followed by MATLAB and EES (Engineering Equation Solver) commercial software. Like experimental investigations, general enhancement in thermal efficiency is reported by researchers. Also, the effect of nanoparticle on pressure drop augmentation as well as enhancement in the convection heat transfer coefficient is studied. Finally, the exergy efficiency and entropy generation rate were investigated by some researchers [58-61]. On the later issue, it was concluded that application of nanofluid enhances the exergy efficiency [62] and lead to a decrease in entropy generation rate [59].

\subsubsection{Governing Equations}

Since most of the analysis are conducted on absorber tube where the flow is mainly turbulent, the governing equations are mainly concerned in this part as:

- Continuity

$$
\frac{\partial\left(\rho u_{i}\right)}{\partial x_{i}}=0
$$

- Momentum equation

$$
\frac{\partial\left(\rho u_{i} u_{j}\right)}{\partial x_{j}}=-\frac{\partial p}{\partial x_{i}}+\frac{\partial}{\partial x_{j}}\left(\left(\mu+\mu_{t}\right)\left(\frac{\partial u_{i}}{\partial x_{j}}+\frac{\partial u_{j}}{\partial x_{i}}\right)-\frac{2}{3}\left(\mu+\mu_{t}\right) \frac{\partial u_{i}}{\partial x_{i}} \delta_{i j}-\frac{2}{3} \rho k \delta_{i j}\right)+F
$$

- Energy equation

$$
\rho C_{p} u_{i} \frac{\partial T}{\partial x_{i}}=\left(k+k_{T}\right) \frac{\partial}{\partial x_{i}}\left(\frac{\partial T}{\partial x_{i}}\right)
$$

where, $k$ stands for thermal conductivity of the fluid, $k_{T}$ as turbulent conductivity, $\mu_{t}$ turbulent dynamic viscosity, $\mu$ dynamic viscosity of the fluid, $C_{p}$ heat capacity of the fluid, $T$ temperature, $u$ fluid velocity, $F$ body force on the fluid, and $x_{i}\left(\right.$ or $\left.x_{j}\right)$ system coordinates (mostly in cylindrical coordinate system for these type of problems) [63].

\subsubsection{Investigations}

The first study in this field was conducted in 2010 by Kasaeian and Sokhansefat [63]. They conducted a CFD simulation to study the effect of $\mathrm{Al}_{2} \mathrm{O}_{3} /$ synthetic oil nanofluid in PTC at $1-5$ vol. \% of $\mathrm{Al}_{2} \mathrm{O}_{3}$. They found that the heat transfer coefficient enhances by nanoparticle volume fraction increase (approximately $14 \%$ enhancement, at $5 \% \mathrm{Al}_{2} \mathrm{O}_{3}$ volumetric concentration). Consequently, they concluded that increasing the temperature (from $300 \mathrm{~K}$ to $500 \mathrm{~K}$ ) demolishes the effect of nanoparticle concentration on enhancing heat transfer coefficient in constant flow rate.

Later, Sokhansefat et al. [10] studied the effect of $\mathrm{Al}_{2} \mathrm{O}_{3}$ / synthetic oil as a working fluid for PTC. They simulated the flow through absorber tube at three volumetric concentrations of $1-5 \%$. Their results suggested that the application of the nanofluid at $5 \%$ volumetric concentration can enhance the convection heat transfer in the PTC by approximately $14-15 \%$. Similar to the results suggested by them in [63] they realized that increasing the temperature (from $300 \mathrm{~K}$ to $500 \mathrm{~K}$ ) has an adverse effect on enhancing the heat transfer coefficient.

Mohammad Zadeh et al. [64] proposed an optimized model coupled with CFD analysis through which they investigated the effect of using $\mathrm{Al}_{2} \mathrm{O}_{3} /$ synthetic oil (with $0-6.5$ vol. \% concentration) as working fluid on the thermal enhancement of PTC. They showed that using the proposed model, the maximum convection heat transfer coefficient of nanofluid could be enhanced by $36 \%$ at $300 \mathrm{~K}$. Additionally, they showed that increasing the temperature (from $300 \mathrm{~K}$ to $500 \mathrm{~K}$ ) decreases the heat transfer coefficient. Finally, they proposed optimum nanofluid concentration is 6.5 vol. \%, for their studied range. 
Mwesigye et al. [61,65,66] conducted five studies using CFD simulations in PTC receive to investigate the effect of different nanofluids on PTC thermal performance. In Reference [65], they used $\mathrm{Al}_{2} \mathrm{O}_{3}$ /synthetic oil nanofluid as working fluid with the volume fraction of up to $8 \%$ to investigate the enhancement of convection heat transfer coefficient as well as thermal efficiency. The results showed at $8 \%$ volume concentration $76 \%$ and $7.6 \%$ increase can be obtained for convection heat transfer and maximum thermal efficiency, respectively. Also the heat transfer coefficient at $6 \%$ and $4 \%$ volume concentration increased by $54 \%$ and $35 \%$, respectively. A significant increase in pressure drop is also reported by the authors, as the volume concentration is reached beyond 4 vol. \%, which in turn emphasized the necessity of more pumping power. This pressure drop increases up to approximately $40 \%$ at $4 \%$ vol. of $\mathrm{Al}_{2} \mathrm{O}_{3}$ in a nanofluid. The effect of temperature increase was on the favor of pressure drop as it causes less pressure drop along the tube with temperature increasing. However, this effect demolishes the effect of nanofluid in increasing thermal efficiency and heat transfer coefficient.

In reference [61] the maximum heat transfer coefficient and thermal efficiency enhancement of $38 \%$ and $15 \%$ were found at $6 \%$ volume concentration of $\mathrm{CuO}$ in $\mathrm{CuO} /$ syltherm 800 nanofluid. Similar to [65] they reported an increase of in pressure drop. Additional simulations were conducted in Reference [66] on $\mathrm{Al}_{2} \mathrm{O}_{3}$ /water nanofluid to minimize entropy generation and find optimum Reynolds number for different volume fractions of $\mathrm{Al}_{2} \mathrm{O}_{3}$ located at different sections of a circular tube. They showed that at a given Reynolds number the performance of heat transfer (Nusselt number) and the value for friction factor is almost the same regardless of the volume fraction. Also, it was proven that there is an optimum cross-section of the tube that causes minimum generation of entropy.

An 18\% enhancement in convection heat transfer coefficient was reported by Basbous et al. [67] in their numerical investigation. They tested the application of $\mathrm{Al}_{2} \mathrm{O}_{3}$ / syltherm 800 nanofluid as working fluid in PTC at different volume concentrations of $1-5 \%$. The proposed model also predicted that increasing the temperature can cause an increase in convection heat transfer coefficient.

A CFD simulation was conducted by Bellos et al. [68] on $\mathrm{Al}_{2} \mathrm{O}_{3}$ /syltherm 800 nanofluid, at $2 \%$ volumetric concentration of $\mathrm{Al}_{2} \mathrm{O}_{3}$, to examine its effect on the thermal performance of PTC. It was concluded that the nanofluid could increase the efficiency of PTC by $4.25 \%$. An interesting result reported by them was the effect of pressurized water as working fluid which enhanced the thermal efficiency by $6.34 \%$. However, authors mentioned that the application of pressurized water requires some effort which makes nanofluid utilization more advantageous overpressure water. It was also suggested a new design for absorber geometry shape of which had a wavy trend, which improved the efficiency by $4.55 \%$ and this design. Furthermore, it was shown that higher temperature levels increase efficiency. This led to heat transfer coefficient improvement (maximum increase of $10.92 \%$ at $350{ }^{\circ} \mathrm{C}$ ). Finally, application of nanofluid did not cause too much pressure drop increase comparing to base fluid (syltherm 800). The pressure drop increase was around $125 \mathrm{~Pa}$ to $202 \mathrm{~Pa}$ for nanofluid and $118 \mathrm{~Pa}$ to 192 Pa for syltherm 800 .

Wang et al. [69] numerically studied with CFD simulation the effect of $\mathrm{Al}_{2} \mathrm{O}_{3} /$ thermal oil nanofluid with different volume fractions ranging $0.5-5 \%$ on the performance of PTC. It was reported the efficiency enhancement around $1.2 \%$ in their model (at $5 \%$ volume fraction). They also found that increasing the nanofluid volume fraction can lead to a slight decrease in longitudinal displacement of the absorber. Similarly, the horizontal displacement of the absorber was reported to slightly decrease by volume fraction increase.

Kaloudis, et al. [70] conducted a CFD simulation to investigate the effect of different volume fraction (0.5-4\%) of $\mathrm{Al}_{2} \mathrm{O}_{3}$ in $\mathrm{Al}_{2} \mathrm{O}_{3}$ /syltherm 800 nanofluid on PTC performance. They used two different modeling for nanofluid: two-phase simulation and one phase simulation. They concluded that utilizing two-phase modeling of nanofluid had more accuracy in the results. More specifically, the numerical results suggested a maximum of $10 \%$ thermal efficiency enhancement at maximum $\mathrm{Al}_{2} \mathrm{O}_{3}$ volume fraction of $4 \%$.

Benabderrahmane et al. [71,72] numerically modeled the effect of utilizing nanofluid as well as internal fins in the receiver of PTC using CFD. In Reference [72], it was concluded that combining 
both internal fins and nanofluid application can enhance the heat transfer behavior of the PTC greatly. To be specific, they utilized four different nanofluids $\left(\mathrm{Al}_{2} \mathrm{O}_{3}\right.$ /Dowtherm $\mathrm{A}, \mathrm{Cu} /$ Dowtherm $\mathrm{A}$, $\mathrm{SiC} /$ Dowtherm A, C/Dowtherm A) at different volumetric concentration of $1 \%$ and found that the metallic nanofluids ( $\mathrm{Cu}$ /Dowtherm) had better thermal enhancement performance comparing with non-metallic ones ( $\mathrm{SiC} /$ Dowtherm A, C/Dowtherm A, $\mathrm{Al}_{2} \mathrm{O}_{3}$ /Dowtherm A,). Also, the friction factor reported to be higher when nanofluid is applied. A $68 \%$ increase in convection heat transfer coefficient was reported [37].

Ghasemi et al. [73] carried out a numerical simulation through which the application of $\mathrm{Al}_{2} \mathrm{O}_{3} /$ water and $\mathrm{CuO} /$ water as a working fluid at different volume fractions, $0.5-3 \%$, in PTC were investigated. They realized that the application of $3 \% \mathrm{CuO} /$ water nanofluid could lead to higher convection heat transfer coefficient comparing with $\mathrm{Al}_{2} \mathrm{O}_{3} /$ water and water itself. Although $\mathrm{CuO} /$ water nanofluid caused $7 \%$ more increase in heat transfer coefficient comparing with $\mathrm{Al}_{2} \mathrm{O}_{3}$ /water nanofluid ( $35 \%$ compared with $28 \%$ enhancement), but the friction factor caused by application of $\mathrm{Al}_{2} \mathrm{O}_{3}$ was lower than the one caused by $\mathrm{CuO}$.

Mwesigye et al. [60] conducted another CFD simulation on $\mathrm{Cu} /$ Therminol VP-1 nanofluid to study the application of nanofluid at different volume fraction (1-6\%) on thermal and thermodynamic performance of PTC. At a maximum $6 \%$ volumetric concentration of $\mathrm{Cu}$, it was observed that the convection heat transfer coefficient and thermal efficiency increase up to $32 \%$ and $12.5 \%$, respectively. Furthermore, the pressure drop through the receiver at $400 \mathrm{~K}$ and Reynolds number of approximately 650,000 increase roughly by more than $100 \%$ (from nearly 3000 to $7734 \mathrm{~Pa} / \mathrm{m}$ ). Finally, the minimum entropy generation rate at a certain Reynolds number was obtained by their model. This point is crucial as it shows the Reynolds number in which we have the maximum heat transfer irreversibility and minimum friction irreversibility. Specifically, there is a maximum $30 \%$ decrease in entropy generation rate at $6 \%$ volume fraction comparing to the base fluid.

Basbous et al. [74] numerically modeled the thermal performance of PTC utilizing different metallic nanofluids. Syltherm 800 as base fluid and $\mathrm{Cu}, \mathrm{CuO}$, and $\mathrm{Al}_{2} \mathrm{O}_{3}$, and $\mathrm{Ag}$ with $5 \%$ volumetric concentrations were considered as studied nanofluids. The results suggested that silver is the best nanoparticle to be used to induce the best thermal enhancement followed by copper, cupric oxide and aluminum oxide with convection heat transfer enhancement of $36 \%, 33 \%, 27 \%$, and $18 \%$, respectively. They also concluded that as the density of the nanoparticle increases, the thermal performance enhances better. Finally $21 \%$ decrease in heat loss was observed.

Toghyani et al. [75] modeled and optimized the effect of different nanoparticles on the performance of the PTC used in a Rankin cycle. $\mathrm{CuO}, \mathrm{SiO}_{2}, \mathrm{TiO}_{2}$, and $\mathrm{Al}_{2} \mathrm{O}_{3}$ were dispersed in Therminol-55 at $2-5.5$ vol. \% for the numerical investigation. The results suggested that using nanofluids in the solution caused slight enhancement in thermal efficiency. Finally, the optimization results revealed that using $\mathrm{Al}_{2} \mathrm{O}_{3} /$ Therminol-55, caused the maximum enhancement in overall exergy efficiency of the system by $11 \%$.

Nayak et al. [76] modeled $\mathrm{Al}_{2} \mathrm{O}_{3} /$ Synthetic oil nanofluid up to $5 \%$ volumetric concentration to investigate and optimize thermal behavior of the PTC. They reported an approximately $7 \%$ enhancement in heat transfer coefficient when $5 \%$ volumetric concentration of $\mathrm{Al}_{2} \mathrm{O}_{3}$ was used comparing with Synthetic oil only.

Ferraro et al. [77] used $\mathrm{Al}_{2} \mathrm{O}_{3}$ /Synthetic oil nanofluid to study the effect of the nanofluid on PTC performance numerically. Their results showed that the thermal efficacy and pressure drop almost stays the same. However, the maximum increase of approximately $60 \%$ was observed at $5 \%$ volumetric concentration of $\mathrm{Al}_{2} \mathrm{O}_{3}$ for convection heat transfer coefficient.

Kharkah et al. [78] conducted a CFD simulation on the receiver system of PTC using $\mathrm{Al}_{2} \mathrm{O}_{3} /$ Synthetic oil nanofluid as working fluid at $5 \%$ volumetric concentration. The enhancement of $14.3 \%$ was reported in the system thermal efficiency.

Mwesigye et al. [59] carried out a CFD simulation aiming to investigate the optimum thermal and thermodynamic performance of PTC. Three different nanofluids, $\mathrm{Cu}, \mathrm{Ag}$, and $\mathrm{Al}_{2} \mathrm{O}_{3}$ dispersed in 
Therminol VP-1, at different volume fractions, 1-6\%, were used. It was found that the Ag/Therminol VP-1 had the highest thermal efficiency enhancement at $6 \%$ volumetric concentration by $13.9 \%$, followed by $\mathrm{Cu} /$ Therminol VP- 1 and $\mathrm{Al}_{2} \mathrm{O}_{3} /$ Therminol VP- 1 by $12.5 \%$ and $7.2 \%$ enhancement, respectively. Also, it was shown that for a particular volume fraction, a maximum thermal efficiency point could be achieved at a certain Reynolds number or flow rate. Furthermore, convection heat transfer enhancement at $6 \%$ volumetric concentration is observed to be $7.9 \%, 6.4 \%$, and $3.9 \%$ for $\mathrm{Ag} /$ Therminol VP-1 Cu/Therminol VP-1 and $\mathrm{Al}_{2} \mathrm{O}_{3}$ /Therminol VP-1, respectively. Finally, the entropy generation rate at lower Reynolds number was observed to reduce as the volume fraction of nanoparticle increases. This reduction is uppermost $(24 \%)$ when $\mathrm{Al}_{2} \mathrm{O}_{3} /$ Therminol VP-1 nanofluid is used. It was mentioned by the authors that the reason for better entropy generation performance of $\mathrm{Al}_{2} \mathrm{O}_{3} /$ Therminol VP-1 nanofluid was probably due to its relatively lower density comparing to silver/Therminol VP-1 (19\%) and copper/Therminol VP-1 (17\%).

Ghasemi et al. [73] simulated $\mathrm{Al}_{2} \mathrm{O}_{3} /$ Therminol 66 nanofluid at different volume fraction (1-4\%) inside the receiver tube using CFD. He reported a slight enhancement in thermal efficiency (around $0.5 \%$ ). At the lowest Reynolds number (approximately 30,000) using 4 vol. $\%$ of $\mathrm{Al}_{2} \mathrm{O}_{3}$ in nanofluid resulted in seven times greater friction coefficient compared to the base fluid. Also, this increase is approximately nine times bigger for the highest Reynolds number $(>250,000)$. The same scenario is true for Nusselt number as it increases by a factor of 2 using $4 \%$ volume fraction of $\mathrm{Al}_{2} \mathrm{O}_{3}$ in a nanofluid.

Bellos et al. [62,79] numerically modeled the effect of $\mathrm{Al}_{2} \mathrm{O}_{3}$ / syltherm 800 and $\mathrm{CuO} /$ syltherm 800 nanofluids to study their effect on thermal enhancement of the PTC. In reference [79] up to $4 \%$ volume fraction of both $\mathrm{Al}_{2} \mathrm{O}_{3}$ and $\mathrm{CuO}$ was examined. They found that $\mathrm{CuO} /$ syltherm 800 has the maximum thermal efficiency of $1.26 \%$ followed by $1.13 \%$ by application of $\mathrm{Al}_{2} \mathrm{O}_{3}$ /syltherm 800 . As for the heat transfer coefficient, the enhancements were $41 \%$ and $35 \%$ for $\mathrm{CuO} /$ syltherm 800 and $\mathrm{Al}_{2} \mathrm{O}_{3} /$ syltherm 800 , respectively. In reference [62] they used up to $6 \%$ volume fraction of both nanoparticles to investigate the effect of the nanofluids in PTC which is used in a trigeneration system. They realized, after optimization, that the use of $\mathrm{CuO}$ nanofluid with $4.35 \%$ volumetric concentration of $\mathrm{CuO}$ in the solar loop along with Toluene in ORC is the optimum choice. They also, found that the maximum energy efficiency enhancement was $1.91 \%$ and $1.17 \%$ for $\mathrm{CuO} /$ syltherm 800 and $\mathrm{Al}_{2} \mathrm{O}_{3}$ / syltherm 800 nanofluid, respectively. They also, reported the maximum exergy enhancement of approximately $1.75 \%$ and $1 \%$ for $\mathrm{CuO} /$ syltherm 800 and $\mathrm{Al}_{2} \mathrm{O}_{3}$ / syltherm 800 nanofluid, respectively.

Two CFD simulations were carried out by Bellos et al. [37,80]. In reference [80] the authors examined $\mathrm{CuO}$ with two base fluids, syltherm 800 and molten salt $\left(60 \% \mathrm{NaNO}_{3}-40 \% \mathrm{KNO}_{3}\right)$ at 6 vol. $\%$. They reported $0.76 \%$ and $0.26 \%$ thermal efficiency enhancement when using $\mathrm{CuO} /$ syltherm 800 and $\mathrm{CuO} /$ molten salt comparing with syltherm 800 and molten salt, respectively. As for convection heat transfer coefficient, $31.5 \%$ and $13.9 \%$ enhancement is observed for $\mathrm{CuO} /$ syltherm 800 and $\mathrm{CuO} / \mathrm{molten}$ salt, respectively. Although, the hydraulic analysis also proved $50 \%$ and $16 \%$ pressure drop increase for $\mathrm{CuO} /$ syltherm 800 and $\mathrm{CuO} /$ molten salt cases, respectively, the demand for pumping work was still low. Hence, this pressure drop increase did not cause so much of a problem. Finally, they commented on exergy efficiency stating that nanofluid application, specifically molten salt nanofluid, can lead to better exergic efficiency. In reference [37] CuO/syltherm 800 nanofluid at 6 vol. \% was used to evaluate the thermal analysis. They also studied the effect of different fins to investigate thermal efficiency enhancement. They realized that the combination of both nanofluids and fins could lead to higher efficiency enhancement. This combination can lead to $1.54 \%$ enhancement in thermal efficiency, whereas with the application of the only nanofluid and only fin this value was calculated as $0.76 \%$ and $1.1 \%$, respectively, compared with smooth pipe with syltherm 800 as working fluid. Convection heat transfer coefficient enhanced by $130 \%$ at $300 \mathrm{~K}$. Similar to their last study, the pressure drop increase (approximately $163 \%$ at $300 \mathrm{~K}$ ) did not cause too much of a problem as the demand for pump work was still relatively low.

Mwesigye et al. [58] carried out a CFD simulation to investigate the effect of SWCNT/Therminol VP-1 nanofluid on thermal and thermodynamic performance of the PTC at $0.25-2.5$ vol. \%. The results 
suggested that application of nanofluid enhances the heat transfer up to $234 \%$ compared with the base fluid due to the high thermal conductivity of SWCNT. Also, thermal efficiency using such nanofluid enhanced up to $4.4 \%$. $70 \%$ reduction in entropy generation rate was observed due to the application of SWCNT. Pumping work, caused by pressure drop, did not increase too much for flow rates lower than $36.74 \mathrm{~m}^{3} / \mathrm{h}$. They, finally, concluded that higher thermal conductivity does not necessarily lead to higher thermal efficiency, since the effect of specific heat capacity also should be considered.

Allouhi et al. [81] numerically modeled the effect of $\mathrm{TiO}_{2}, \mathrm{CuO}$, and $\mathrm{Al}_{2} \mathrm{O}_{3}$ nanoparticles dispersed in Therminol VP-1 at 1-5 vol. \% on thermal performance of PTC. Slight thermal efficiency enhancement was predicted by their model for 3 vol. \%. CuO/ Therminol VP-1 nanofluid showed better exergy and energy performance comparing with other nanofluids. More specifically, it can enhance the convection heat transfer by a maximum $83 \%$.

Bellos et al. [82] numerically investigated the effect of $\mathrm{TiO}_{2} /$ Syltherm 800, $\mathrm{Al}_{2} \mathrm{O}_{3} /$ Syltherm 800, and $\mathrm{TiO}_{2} / \mathrm{Al}_{2} \mathrm{O}_{3} /$ Syltherm 800 (hybrid nanofluid) at 3 vol. \% for each $\mathrm{TiO}_{2}$ and $\mathrm{Al}_{2} \mathrm{O}_{3}$ as well as 1.5 vol. $\%$ for $\mathrm{TiO}_{2} / \mathrm{Al}_{2} \mathrm{O}_{3}$ on PTC thermal performance at different temperature (300-650 K) and $150 \mathrm{~L} / \mathrm{min}$ flow rate. It was found that the efficiency of PTC can be enhanced up to $0.74 \%$ when using hybrid nanofluid and 0.34 for both mono nanofluids. Enhancements of $142.1 \%, 35.2 \%$, and $34.9 \%$ in heat transfer coefficient was observed for hybrid nanofluid, $\mathrm{Al}_{2} \mathrm{O}_{3}$ /Syltherm 800, and $\mathrm{TiO}_{2} /$ Syltherm, respectively. Finally, the model suggested higher exergy efficiency for nanofluids in comparison with base fluid at higher temperatures.

Bellos et al. [38] studied numerically the effect of different nanoparticles, $\mathrm{Cu}, \mathrm{CuO}, \mathrm{SiO}_{2}, \mathrm{Al}_{2} \mathrm{O}_{3}$, $\mathrm{Fe}_{2} \mathrm{O}_{3}$, and $\mathrm{TiO}_{2}$ dispersed into Syltherm 800 with different volume concentrations ranging 1-6 vol. \% on PTC thermal efficiency. They found that the $\mathrm{Cu}$ /syltherm 800 nanofluid had the best thermal performance with the maximum thermal efficiency enhancement of $2.2 \%$ at 6 vol. $\%, 600 \mathrm{~K}$ inlet temperature, and $50 \mathrm{~L} / \mathrm{min}$ flow rate. At $4 \%$ volume fraction $\mathrm{Cu}$ had the highest efficiency increase of $0.54 \%$ followed by $0.46 \%$ for $\mathrm{CuO}, 41 \%$ for $\mathrm{Fe}_{2} \mathrm{O}_{3}, 0.35 \%$ for $\mathrm{TiO}_{2}, 0.35 \%$ for $\mathrm{Al}_{2} \mathrm{O}_{3}$, and $0.19 \%$ for $\mathrm{SiO}_{2}$. The same trend is observed for enhancement in heat transfer coefficient with

$\mathrm{Cu}$ is having the highest enhancement with $24.42 \%$ and $\mathrm{SiO}_{2}$ with $7.28 \%$ the lowest enhancement at $4 \%$ volumetric concentration.

Kasaeian et al. [83] modeled the effect of MWCNT/thermal oil nanofluid at 3, 6 vol. \% of MWCNT on thermal performance of the PTC. They found $15 \%$ enhancement in heat transfer coefficient.

Bilal et al. [84] modeled the effect of $\mathrm{Fe}_{3} \mathrm{O}_{4}$ / water nanofluid at $0.6 \%$ vol. of $\mathrm{Fe}_{3} \mathrm{O}_{4}$ on heat transfer behavior of the PTC. It was shown that the nanofluid could enhance the Nusselt number up to $56 \%$ at 6 vol. $\%$ of $\mathrm{Fe}_{3} \mathrm{O}_{4}$. Also, the maximum thermal efficiency enhancement (combination of nanofluid application with twisted tape) was $1.6 \%$.

Khular et al. [30] conducted numerical modeling in which they examined the effect of $0.05 \mathrm{vol} . \%$ $\mathrm{Al}_{2} \mathrm{O}_{3}$ in $\mathrm{Al}_{2} \mathrm{O}_{3} /$ Therminol VP-1 nanofluid on PTC thermal behavior. They suggested $5-10 \%$ enhancement in thermal efficiency due to the application of nanofluid.

A CFD simulation was conducted by Hatami et al. [85] using $8 \%$ vol. of $\mathrm{Cu}, \mathrm{Fe}_{3} \mathrm{O}_{4}, \mathrm{Al}_{2} \mathrm{O}_{3}$, and $\mathrm{TiO}_{2}$ dispersed in water and investigated the effect of nanofluid in heat transfer of PTC. It was shown that $\mathrm{Cu}$ nanoparticles show better thermal enhancement comparing with $\mathrm{Fe}_{3} \mathrm{O}_{4}, \mathrm{Al}_{2} \mathrm{O}_{3}$, and $\mathrm{TiO}_{2}$.

Finally, Minea et al. [86] simulated the effect of hybrid nanofluid on thermal performance of PTC. Three different hybrid nanofluids were selected: $\mathrm{Ag} / \mathrm{MgO}$ (1.5 and 2 vol. \%), $\mathrm{Al}_{2} \mathrm{O}_{3} / \mathrm{Cu}(0.1$ and 1 vol. \%), and $\mathrm{GO} / \mathrm{Co}_{3} \mathrm{O}_{4}(0.05$ and 0.15 vol. \%). The nanoparticles were dispersed in either water or the hybrid base fluid consisting of $60 \mathrm{vol}$. $\%$ EG and 40 vol. \% water. It was found that although hybrid nanofluid with hybrid base fluid (water and EG) had better thermal enhancement (about 5-6\%), it introduces higher pressure drop increase (approximately 5000\%) to the system compared with hybrid nanofluid with water as the base fluid. Therefore, it was concluded that the application of hybrid water base nanofluid with acceptable heat transfer enhancement and lower pressure drop increase would be a better choice over hybrid nanofluid with hybrid base water. The water-based hybrid nanofluids 
with $2 \% \mathrm{Ag}-\mathrm{MgO}$ offers the highest values in collector efficiency (about 60\%). Convection heat transfer coefficient increase between $115-125 \%$ using $0.15 \% \mathrm{GO} / \mathrm{Co}_{3} \mathrm{O}_{4}$ dispersed in W:EG (40:60).

Table A2 at Appendix A summarizes the details and important notes about the above studies.

\section{Conclusions}

After a complete review of the application of nanofluid as working fluid in PTC, the following advantages and disadvantages can be listed:

Advantages

- Among all studied nanoparticles, application of copper nanoparticles contributed to better thermal efficiency enhancement in metallic nanofluids, followed by $\mathrm{CuO}, \mathrm{TiO}_{2}$, and $\mathrm{Al}_{2} \mathrm{O}_{3}$.

- For non-metallic nanofluids, MWCNT nanoparticle can lead to the highest thermal efficiency enhancement [40].

- Although, there are some studies $[42,65,66,81]$ reporting no significant enhancement on the thermal efficiency of PTC thermal efficiency even using nanofluids, generally it can be concluded that application of nanofluid can enhance the thermal efficiency of PTC. The maximum reported enhancement was approximately $44 \%$ for $\mathrm{CuO} /$ water nanofluid by Sharma et al. [41].

- Convection heat transfer, also, is enhanced by the nanofluid application in PTC. This increase can be shown in both convection heat transfer coefficient and Nusselt number. The maximum reported convection heat transfer coefficient enhancement was 234\% in Mwesigye et al. [58] when using MWCNT/Therminol VP-1 nanofluid as working fluid.

- Exergy efficiency also enhances with the application of nanofluids.

- Based on studies which have done by Mwesigye et al. [58-61,66] the entropy generation rate can be reduced by application of nanofluid.

Disadvantages

- Increasing in pressure drop through PTC receiver tube, due to the presence of nanoparticles is the main design problem in PTC. This effect is mainly discussed by Mwesigye et al. [58-61] and Bellos et al. $[37,80]$. Although, it was reported that pressure drop increases by boosting the volumetric concentration, but in the studies conducted by Bellos et al. $[37,80]$ this increment was in the level that did not have too much demand of pumping work raise.

- Capital cost is another major drawback in the application of nanofluid in PTC, since the cost for nanoparticle is much higher than conventional fluids such as water and different oils.

Challenges

All in all, it is evident that increasing the number of nanoparticles in nanofluids can lead to higher thermal and exergy efficiency. However, that can lead to higher pressure drop which consequently may contribute to higher pumping power of the system. Considering those two factors emphasizes on finding the optimum concentration value of the nanoparticle for each specific nanofluid used in a PTC by which the acceptable thermal efficiency is achieved as well as avoiding the excessive pressure drop increase in the system future works

Finally, it is worth noting there were some innovative investigations that could change the use of nanofluid in future a lot. As an example, the application of ferrofluids, a type of nanofluids, which was done by Alsaady et al. [55] at 0.05 vol. \% which is applied in the presence of magnetic brought a significant enhancement in thermal efficiency of $25 \%$.

Author Contributions: All authors contributed equally.

Funding: This research received no external funding.

Conflicts of Interest: The authors declare no conflict of interest. 


\section{Nomenclature}

CPT Concentrating parabolic through

CNT Carbon nanotube

DASC Direct absorption solar collector

EG Ethylene glycol

ETC Evacuated tube collectors

FPT Flat plate solar collectors

MWCNT Multi-wall carbon nanotube

NCPSC Nanofluid based concentrating parabolic solar collectors

NP Nanoparticles

ORC Organic Rankin cycle

PTC Parabolic trough collectors

PTSC Parabolic trough solar collectors

OLE Olive leaf extract

$\mathrm{BH} \quad$ Barley husk

$\varphi \quad$ Nanoparticle volume fraction

$\eta_{\text {th }} \quad$ Thermal efficiency enhancement (\%)

$\mathrm{h} \quad$ Convection heat transfer coefficient $\left(\mathrm{W} / \mathrm{m}^{2} \mathrm{~K}\right)$

$\Delta \mathrm{p} \quad$ Pressure drop increase (\%)

vol. \% Nanoparticle volume percentage

wt $\% \quad$ Nanoparticle weight percentage 


\section{Appendix A}

Table A1. Summary of experimental studies conducted on the nanofluid application in PTC.

\begin{tabular}{|c|c|c|c|c|c|c|c|c|}
\hline \multirow{2}{*}{ Study } & \multirow{2}{*}{ Nanofluid } & \multicolumn{3}{|c|}{ Nanoparticle } & \multicolumn{3}{|c|}{ Max. Increase \% } & \multirow{2}{*}{ Comment(s) } \\
\hline & & Type & $\varphi_{\max }$ & Size (nm) & $\eta_{\text {th }}$ & $\mathbf{h}$ & $\Delta \mathbf{P}$ & \\
\hline Sharma et al. [41] & Water & $\mathrm{Al}_{2} \mathrm{O}_{3}, \mathrm{CuO}$ & 0.05 vol. $\%$ & $20-40$ & 44 & - & - & $\mathrm{CuO}$ had the highest thermal efficiency. \\
\hline Kasaeian et al. [45] & Mineral oil & MWCNT & $0.3 \mathrm{wt} \%$ & 10 & 7 & - & - & The first study uses carbon nanotube as nanoparticle in PTC \\
\hline Siva Reddy et al. [46] & Water & $\mathrm{Al}_{2} \mathrm{O}_{3}$ & 0.06 vol. $\%$ & $<50$ & 28.98 & - & - & $\begin{array}{l}\text { Minimization of losses and prevention of nanoparticles settlement can enhance the } \\
\text { thermal efficiency of PTC }\end{array}$ \\
\hline Kandwal et al. [40] & EG, Water & $\mathrm{CuO}$ & 0.1 vol. $\%$ & $25-55$ & 82 & - & - & $\begin{array}{c}\mathrm{CuO} / \text { water nanofluid had better thermal efficiency in comparison with } \mathrm{CuO} / \mathrm{EG} \\
\text { nanofluid }\end{array}$ \\
\hline Chaudhari et al. [47] & Water & $\mathrm{Al}_{2} \mathrm{O}_{3}$ & 0.1 vol. $\%$ & 40 & 7 & 32 & - & $\begin{array}{l}\text { Nusselt number increases by application of nanofluid } \\
\text { Although, an asymptotic trend was observed after naopartcle volumetric concentration } \\
\text { of } 0.2 \% \text {, the maximum efficiency achieved at } 0.5 \% \text { volume fraction. }\end{array}$ \\
\hline Subramani et al. [49] & Water & $\mathrm{Al}_{2} \mathrm{O}_{3}$ & 0.5 vol. $\%$ & $40-50$ & 8.54 & - & - & $\begin{array}{l}\text { The optimal nanoparticle concentration was proposed to be } 0.2 \% \text { by parametric study } \\
\text { (Semi) empirical equations was obtained for Nusselt number, friction factor and } \\
\text { collector efficiency using experimental data. }\end{array}$ \\
\hline Kasaeian et al. [44] & EG & MWCNT, $\mathrm{SiO}_{2}$ & 0.3 vol. $\%$ & 4,6 & 30.4 & - & - & $\begin{array}{l}\text { MWCNT/EG was more efficient nanofluid in term of higher thermal efficiency than } \\
\qquad \mathrm{SiO}_{2} / \mathrm{EG}\end{array}$ \\
\hline Sekhar et al. [50] & Water & $\mathrm{CeO}_{2}, \mathrm{Al}_{2} \mathrm{O}_{3}, \mathrm{TiO}_{2}$ & 3 vol. \% & - & 27 & - & - & $\begin{array}{l}\left(\mathrm{CeO}_{2}\right) / \text { water nanofluid had the highest thermal efficiency enhancement followed by } \\
\text { alumina and titania nanofluids. }\end{array}$ \\
\hline Coccia et al. [42] & Water & $\begin{array}{l}\mathrm{Fe}_{2} \mathrm{O}_{3}, \mathrm{SiO}_{2}, \mathrm{TiO}_{2} \\
\mathrm{ZnO}, \mathrm{Al}_{2} \mathrm{O}_{3}, \mathrm{Au}\end{array}$ & $20 \mathrm{wt} \%$ & - & $\sim 0$ & $\sim 50$ & - & Application of nanofluid didn't cause thermal efficiency enhancement. \\
\hline Rehan et al. [51] & Water & $\mathrm{Al}_{2} \mathrm{O}_{3}, \mathrm{Fe}_{2} \mathrm{O}_{3}$ & $0.30 \mathrm{wt} \%$ & $20-40$ & 13 & - & - & $\begin{array}{l}\mathrm{Al}_{2} \mathrm{O}_{3} / \text { water had the higher thermal efficiency enhancement compared to } \\
\qquad \mathrm{Fe}_{2} \mathrm{O}_{3} / \text { water nanofluid. }\end{array}$ \\
\hline Subramani et al. [52] & Water & $\mathrm{TiO}_{2}$ & 0.5 vol. $\%$ & 20 & 9 & 23 & - & Nanofluid has higher absorbed energy factor compared with the base fluid. \\
\hline Marefati et al. [53] & Water & $\mathrm{Al}_{2} \mathrm{O}_{3}, \mathrm{CuO}, \mathrm{SiC}$ & 5 vol. \% & - & - & $\sim 32$ & - & $\begin{array}{c}\mathrm{CuO} / \text { water nanofluid is the best option for thermal efficiency enhancement followed } \\
\text { by alumina and } \mathrm{SiC} \text { nanofluid. }\end{array}$ \\
\hline Okonkwo et al. [54] & Therminol VP-1 & $\mathrm{Al}_{2} \mathrm{O}_{3}, \mathrm{CuO}, \mathrm{Fe}_{3} \mathrm{O}_{4}$ & 3 vol. $\%$ & - & 0.22 & - & - & $\begin{array}{l}\mathrm{Al}_{2} \mathrm{O}_{3} / \text { Therminol VP-1 nanofluid is the best practical fluid to achieve the highest } \\
\text { efficiency followed by } \mathrm{CuO} / \text { Therminol VP-1, and } \mathrm{Fe}_{3} \mathrm{O}_{4} / \text { Therminol. }\end{array}$ \\
\hline Alsaady et al. [55] & - & Magnetic nanofluids & 0.05 vol. $\%$ & & 25 & & & $\begin{array}{c}\text { Application of ferrofluid in PTC seems to be a promising field of study. } \\
\text { The thermal efficiency of parabolic trough linear concentrator collector was } \\
\text { experimentally investigated }\end{array}$ \\
\hline De Los Rios et al. [56] & Water & $\mathrm{Al}_{2} \mathrm{O}_{3}$ & 3 vol. \% & 10 & 28 & - & - & $\begin{array}{l}\text { The incident angle of the collector had an important role in thermal efficiency } \\
\text { enhancement of the collector (small increase in incident angle can cause thermal } \\
\text { efficiency enhancement) }\end{array}$ \\
\hline Okonkwo et al. [57] & Pressurized water & 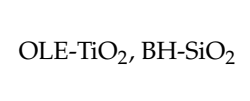 & Up to 0.05 vol. $\%$ & 70,100 & 0.08 & 138 & 14.25 & $\begin{array}{l}\text { This study was the first effort in the application of green-synthesized nanofluid in PTC. } \\
\text { Application of water/OLE-TiO } 2 \text { nanofluids led to higher thermal efficiency increase, } \\
\text { compared with the base fluid. }\end{array}$ \\
\hline Menbari et al. [48] & Water & $\mathrm{CuO}$ & Up to 0.008 vol. $\%$ & $<100 \mathrm{~nm}$ & $52 \%$ & - & - & $\begin{array}{c}\text { A general trend of increasing thermal efficiency (ranging from } 18-52 \% \text { ) was observed } \\
\text { by nanoparticle volume fraction increase (from } 0.002 \% \text { to } 0.008 \% \text { increase), when } \\
\text { water/CuO nanofluid was used in direct absorption parabolic trough collector by } \\
\text { comparison with the base fluid }\end{array}$ \\
\hline
\end{tabular}


Table A2. Summary of numerical studies conducted on the nanofluid application in PTC.

\begin{tabular}{|c|c|c|c|c|c|c|c|c|c|}
\hline \multirow{2}{*}{ Study } & \multirow{2}{*}{ Method } & \multirow{2}{*}{ Nanofluid } & \multicolumn{3}{|c|}{ Nanoparticle } & \multicolumn{3}{|c|}{ Max. Increase \% } & \multirow{2}{*}{ Comment(s) } \\
\hline & & & Type & $\varphi_{\max }$ & Size (nm) & $\eta_{\text {th }}$ & h & $\Delta \mathbf{P}$ & \\
\hline Kasaeian et al. [63] & CFD & Synthetic oil & $\mathrm{Al}_{2} \mathrm{O}_{3}$ & 5 vol. \% & - & - & $\sim 14$ & - & $\begin{array}{l}\text { The first study on nanofluid application in PTC. } \\
\text { Temperature increase demolishes the nanofluid effect }\end{array}$ \\
\hline Sokhansefat et al. [10] & CFD & Synthetic oil & $\mathrm{Al}_{2} \mathrm{O}_{3}$ & 5vol. \% & 10 & - & $\sim 14$ & - & $\begin{array}{c}\text { Temperature increase has negative effect on PTC while utilizes the } \\
\text { nanofluid }\end{array}$ \\
\hline Zadeh et al. [64] & CFD & Synthetic oil & $\begin{array}{l}\mathrm{Al}_{2} \mathrm{O}_{3} \\
\mathrm{Al}_{2} \mathrm{O}_{3}\end{array}$ & 5vol. \% & 10 & - & 36 & - & Proposed an optimized value for $\varphi=6.5 \%$ vol. \\
\hline Mwesigye et al. [65] & CFD & Synthetic oil & $\mathrm{Al}_{2} \mathrm{O}_{3}$ & 8 vol. \% & 28 & 7.6 & 76 & $\sim 40$ & $\begin{array}{l}\text { Proposed an optimized value for } \varphi=6.5 \text { vol. } \\
\text { Receiver thermal performance can be enhanced greatly by increasing inlet }\end{array}$ \\
\hline Mwesigye et al. [61] & CFD & Syltherm800 & $\mathrm{CuO}$ & 6 vol. \% & - & 15 & 38 & - & $\begin{array}{l}\text { Keceiver thermal perrormance can be ennancea greatly by increasing inlet } \\
\text { temperature and low flow rate }\end{array}$ \\
\hline Mwesigye et al. [66] & CFD & Water & $\mathrm{Al}_{2} \mathrm{O}_{3}$ & 6 vol. \% & 28 & - & - & - & $\begin{array}{l}\text { There is an optimum cross-section of the tube that causes minimum } \\
\text { generation of entropy. }\end{array}$ \\
\hline Basbous et al. [67] & Model & Syltherm 800 & $\mathrm{Al}_{2} \mathrm{O}_{3}$ & 5 vol. \% & - & - & 18 & - & $\begin{array}{l}\text { Increasing the temperature can cause an increase in convection heat } \\
\text { transfer coefficient. }\end{array}$ \\
\hline Bellos et al. [68] & CFD & Thermal oil & $\mathrm{Al}_{2} \mathrm{O}_{3}$ & 2 vol. \% & 20 & 4.25 & 10.95 & $\sim 10$ & $\begin{array}{c}\text { Increasing the temperature can cause an increase in convection heat } \\
\text { transfer coefficient. } \\
\text { Combination of enhanced geometry and the nanofluid application gives } \\
\text { the highest thermal efficiency }\end{array}$ \\
\hline Wang et al. [69] & CFD & Thermal oil & $\mathrm{Al}_{2} \mathrm{O}_{3}$ & 5 vol. \% & 28 & 1.2 & - & - & $\begin{array}{l}\text { Increasing the nanofluid volume fraction can lead to a slight decrease in } \\
\text { longitudinal and horizontal displacement of the absorber. }\end{array}$ \\
\hline Kaloudis et al. [70] & CFD & Syltherm 800 & $\mathrm{Al}_{2} \mathrm{O}_{3}$ & 4 vol. \% & 38 & 10 & - & - & $\begin{array}{l}\text { Utilizing two-phase modeling of nanofluid had more accurate results, in } \\
\text { comparison with single phase modeling }\end{array}$ \\
\hline Amina et al. [72] & CFD & Dowtherm A & $\mathrm{Al}_{2} \mathrm{O}_{3}, \mathrm{Cu}, \mathrm{SiC}, \mathrm{C}$ & 1 vol. \% & 13 & - & - & - & $\begin{array}{l}\text { Copper/Dowtherm A combined with internal fin gives the highest } \\
\text { convection heat transfer coefficient followed by Carbon/Dowtherm A, } \\
\text { Silicon carbide/Dowtherm A, and alumina/Dowtherm A. }\end{array}$ \\
\hline Benabderrahmane et al. [71] & CFD & Therminol VP-1 & CNT & 1 vol. \% & - & - & - & - & $\begin{array}{l}\text { Thermal enhancement was observed due to addition of nanoparticle. } \\
\mathrm{CuO} / \text { water nanofluid works better than } \mathrm{Al}_{2} \mathrm{O}_{3} / \text { water. }\end{array}$ \\
\hline Ghasemi et al. [87] & CFD & Water & $\mathrm{Al}_{2} \mathrm{O}_{3}, \mathrm{CuO}$ & 3 vol. \% & 30 & - & 35 & - & $\begin{array}{l}\text { The friction factor caused by application of } \mathrm{Al}_{2} \mathrm{O}_{3} \text { was lower than the one } \\
\text { caused by } \mathrm{CuO} \text {. }\end{array}$ \\
\hline Mwesigye et al. [60] & CFD & Therminol VP-1 & $\mathrm{Cu}$ & 6 vol. \% & $<100$ & 12.5 & 32 & $\sim 158$ & $\begin{array}{l}\text { There is a maximum } 30 \% \text { decrease in entropy generation rate at } 6 \% \\
\text { volume fraction, comparing to base fluid. }\end{array}$ \\
\hline Basbous et al. [74] & Model & Syltherm 800 & $\mathrm{Cu}, \mathrm{CuO}, \mathrm{Al}_{2} \mathrm{O}_{3}, \mathrm{Ag}$ & 5 vol. \% & $<100$ & - & 36 & - & $\begin{array}{l}\text { Silver is the best nanoparticle to be used to induce the best thermal } \\
\text { enhancement followed by copper, cupric oxide and aluminum oxide. } \\
\text { Application of } \mathrm{CuO} \text { causes the highest energy and exergy efficiency }\end{array}$ \\
\hline Toghyani et al. [75] & Model & Therminol-55 & $\mathrm{CuO}, \mathrm{SiO}_{2}, \mathrm{TiO}_{2}, \mathrm{Al}_{2} \mathrm{O}_{3}$ & 5.5 vol. $\%$ & - & $\sim 0$ & - & - & $\begin{array}{l}\text { followed by } \mathrm{TiO}_{2}, \mathrm{Al}_{2} \mathrm{O}_{3} \text { and } \mathrm{SiO}_{2} \text {. } \\
\text { Application of nanofluid causes a slight increase in thermal efficiency. } \\
\text { Optimization results indicated that using } \mathrm{Al}_{2} \mathrm{O}_{3} / \text { Therminol-55 causes the } \\
\text { maximum enhancement in overall exergy efficiency of the system by } 11 \% \text {. }\end{array}$ \\
\hline Nayak et al. [76] & Model & Synthetic oil & $\mathrm{Al}_{2} \mathrm{O}_{3}$ & 5 vol. \% & 10 & - & $\sim 7$ & - & $\begin{array}{l}\text { New optimization algorithm to optimize the thermal analysis of PTC was } \\
\text { introduced. }\end{array}$ \\
\hline Ferraro et al. [77] & Model & Synthetic oil & $\mathrm{Al}_{2} \mathrm{O}_{3}$ & 5 vol. \% & 13 & $\sim 0$ & $\sim 60$ & $\sim 0$ & $\begin{array}{l}\text { No significant increase was observed for pressure loss and thermal } \\
\text { efficiency. However, the application of nanofluid led to lower needed } \\
\text { pumping power. }\end{array}$ \\
\hline Kharkah et al. [78] & CFD & Synthetic oil & $\mathrm{Al}_{2} \mathrm{O}_{3}$ & 5 vol. \% & - & 14.3 & - & - & $\begin{array}{l}\text { Increasing the ambient temperature difference and heat transfer fluid } \\
\text { temperature can lead to lower thermal efficiency. }\end{array}$ \\
\hline
\end{tabular}


Table A2. Cont.

\begin{tabular}{|c|c|c|c|c|c|c|c|c|c|}
\hline \multirow{2}{*}{ Study } & \multirow{2}{*}{ Method } & \multirow{2}{*}{ Nanofluid } & \multicolumn{3}{|c|}{ Nanoparticle } & \multicolumn{3}{|c|}{ Max. Increase \% } & \multirow{2}{*}{ Comment(s) } \\
\hline & & & Type & $\varphi_{\max }$ & Size (nm) & $\eta_{\text {th }}$ & h & $\Delta \mathbf{P}$ & \\
\hline Mwesigye et al. [59] & CFD & Therminol VP-1 & $\mathrm{Cu}, \mathrm{Ag}, \mathrm{Al}_{2} \mathrm{O}_{3}$ & 6 vol. \% & $<100$ & 13.9 & 7.9 & - & $\begin{array}{l}\text { Dispersion of Ag had the highest thermal efficiency enhancement } \\
\text { followed by } \mathrm{Cu} \text { and } \mathrm{Al}_{2} \mathrm{O}_{3,} \\
\text { Maximum entropy generation rate decrease of } 24 \% \text { at lower Reynolds } \\
\text { number was observed when } \mathrm{Al}_{2} \mathrm{O}_{3} / \text { Therminol VP-1 nanofluid is used }\end{array}$ \\
\hline Ghasemi et al. [87] & CFD & Therminol-66 & $\mathrm{Al}_{2} \mathrm{O}_{3}$ & 4 vol. \% & 20 & $\sim 0.5$ & - & - & $\begin{array}{l}\text { Nusselt number increases considerably by using nanofluid, compared to } \\
\text { the base fluid }\end{array}$ \\
\hline Bellos et al. [79] & Model & Syltherm 800 & $\mathrm{Al}_{2} \mathrm{O}_{3}, \mathrm{CuO}$ & 4 vol. \% & - & 1.26 & 41 & - & $\begin{array}{l}\text { They found that } \mathrm{CuO} / \text { syltherm } 800 \text { have the maximum thermal } \\
\text { efficiency followed by } \mathrm{Al}_{2} \mathrm{O}_{3} / \text { syltherm } 800 \text {. }\end{array}$ \\
\hline Bellos et al. [62] & Model & Syltherm 800 & $\mathrm{Al}_{2} \mathrm{O}_{3}, \mathrm{CuO}$ & 6 vol. \% & - & 1.91 & - & - & $\begin{array}{l}\text { After optimization, the use of } \mathrm{CuO} \text { nanofluid with } 4.35 \% \text { volumetric } \\
\text { concentration of CuO in the solar loop along with Toluene in organic } \\
\text { Rankin cycle was the optimum choice. }\end{array}$ \\
\hline Bellos et al. [80] & CFD & $\begin{array}{l}\text { Syltherm } 800 \\
\text { Molten salt }\end{array}$ & $\mathrm{CuO}$ & 6 vol. \% & - & 0.76 & 31.5 & 50 & $\begin{array}{l}\mathrm{CuO} / \text { syltherm } 800 \text { had better thermal efficiency than } \mathrm{CuO} / \text { molten salt } \\
\text { nanofluid. }\end{array}$ \\
\hline Bellos et al. [37] & CFD & Syltherm 800 & $\mathrm{CuO}$ & 6 vol. \% & - & 1.54 & 130 & $\sim 163$ & $\begin{array}{l}\text { Combination of both nanofluids and fins can lead to higher efficiency } \\
\text { enhancement, convection heat transfer, and pressure drop }\end{array}$ \\
\hline Mwesigye et al. [58] & CFD & Therminol VP-1 & SWCNT & 2.5 vol. $\%$ & 10 & 4.4 & 234 & - & $\begin{array}{l}\text { Higher thermal conductivity doesn't necessarily lead to higher thermal } \\
\text { efficiency, since the effect of specific heat capacity also should be } \\
\text { considered }\end{array}$ \\
\hline Allouhi et al. [81] & Model & Therminol VP-1 & $\mathrm{TiO}_{2}, \mathrm{CuO}, \mathrm{Al}_{2} \mathrm{O}_{3}$ & 5 vol. $\%$ & - & $\sim 0$ & 83 & - & $\begin{array}{c}\mathrm{CuO} / \text { Therminol VP-1 nanofluid showed the best exergy and energy } \\
\text { performance followed by } \mathrm{TiO}_{2} \text { and } \mathrm{Al}_{2} \mathrm{O}_{3}\end{array}$ \\
\hline Bellos et al. [82] & Model & Syltherm 800 & $\begin{array}{l}\mathrm{TiO}_{2}, \mathrm{Al}_{2} \mathrm{O}_{3} \text {, and } \\
\mathrm{TiO}_{2} / \mathrm{Al}_{2} \mathrm{O}_{3}\end{array}$ & 3 vol. \% & - & 0.74 & 142.1 & - & $\begin{array}{l}\mathrm{TiO}_{2} / \mathrm{Al}_{2} \mathrm{O}_{3} \text { based nanofluid had highest performance, followed by } \mathrm{TiO}_{2} \\
\text { and } \mathrm{Al}_{2} \mathrm{O}_{3}\end{array}$ \\
\hline Bellos et al. [38] & Model & Syltherm 800 & $\begin{array}{c}\mathrm{Cu}, \mathrm{CuO}, \mathrm{SiO}_{2} \\
\mathrm{Al}_{2} \mathrm{O}_{3}, \mathrm{Fe}_{2} \mathrm{O}_{3}, \mathrm{TiO}_{2}\end{array}$ & 6 vol. \% & - & 2.2 & $\sim 24.4$ & - & $\begin{array}{l}\mathrm{Cu} \text { had the highest efficiency increase of } 2.2 \% \text { followed by } \mathrm{CuO}, \mathrm{Fe}_{2} \mathrm{O}_{3} \\
\qquad \mathrm{TiO}_{2}, \mathrm{Al}_{2} \mathrm{O}_{3} \text {, and } \mathrm{SiO}_{2}\end{array}$ \\
\hline Kasaeian et al. [83] & Model & Thermal oil & MWCNT & 6 vol. \% & - & - & 15 & - & $\begin{array}{l}\text { Convection heat loss increased by } 220 \% \text { in nanofluid; when the } \\
\text { temperature increased from } 30 \text { to } 100 \text {. }\end{array}$ \\
\hline Bilal et al. [84] & Model & Water & $\mathrm{Fe}_{3} \mathrm{O}_{4}$ & 0.6 vol. \% & - & 1.6 & 87 & - & $\begin{array}{c}56 \% \text { enhancement was observed for Nusselt number at } 0.6 \text { vol. \% of } \\
\text { nanoparticles and highest Reynolds number. } \\
\text { Combination of the fin and nanofluid application can result in a } \\
\text { maximum } 87 \% \text { increase in heat transfer coefficient. }\end{array}$ \\
\hline Khular et al. [30] & Model & Therminol VP-1 & $\mathrm{Al}_{2} \mathrm{O}_{3}$ & 0.05 vol. $\%$ & 5 & $5-10$ & - & - & $\begin{array}{l}\text { To obtain the favorable thermal efficiency and maximum outlet } \\
\text { temperature, there should be optimizations on various variables such as } \\
\text { nanoparticle shape, size, and material. }\end{array}$ \\
\hline Hatami et al. [85] & CFD & Water & $\begin{array}{l}\mathrm{Cu}, \mathrm{Fe}_{3} \mathrm{O}_{4}, \mathrm{Al}_{2} \mathrm{O}_{3} \\
\mathrm{TiO}_{2}\end{array}$ & 8 vol. \% & - & - & - & - & $\begin{array}{l}\text { Cu nanoparticles shows the best thermal enhancement comparing with } \\
\qquad \mathrm{Fe}_{3} \mathrm{O}_{4}, \mathrm{Al}_{2} \mathrm{O}_{3}, \mathrm{TiO}_{2} \\
\text { Although hybrid nanofluid with hybrid base fluid (water and EG) had } \\
\text { better thermal enhancement, it introduces higher pressure drop increase } \\
\text { to the system, comparing with hybrid nanofluid with water as the base }\end{array}$ \\
\hline Minea et al. [86] & CFD & $\begin{array}{l}\text { Water, Water/EG } \\
\quad(40 \%: 60 \%)\end{array}$ & $\begin{array}{l}\mathrm{Ag} / \mathrm{MgO}, \mathrm{Al}_{2} \mathrm{O}_{3} / \mathrm{Cu} \\
\mathrm{GO} / \mathrm{Co}_{3} \mathrm{O}_{4}\end{array}$ & 2 vol. \% & & $\sim 5-6$ & $115-125$ & $\sim 5000$ & $\begin{array}{l}\text { fluid. } \\
\text { The application of hybrid water base nanofluid with acceptable heat } \\
\text { transfer enhancement and lower pressure drop would be a better choice } \\
\text { over hybrid nanofluid with hybrid base fluid (Water/EG). } \\
\text { Convection heat transfer coefficient increase between } 115-125 \% \text { using } \\
0.15 \% \mathrm{GO} / \mathrm{Co}_{3} \mathrm{O}_{4} / \mathrm{W}-\mathrm{EG}(40 \%: 60 \%) \text {. }\end{array}$ \\
\hline
\end{tabular}




\section{References}

1. Choi, S.; Gray, M.L.; Jones, C.W. Amine-Tethered Solid Adsorbents Coupling High Adsorption Capacity and Regenerability for $\mathrm{CO}_{2}$ Capture from Ambient Air. ChemSusChem 2011, 4, 628-635. [CrossRef] [PubMed]

2. Earth's $\mathrm{CO}_{2}$ Home Page. 2019. Available online: https://www.co2.earth/Jan23 (accessed on 29 December 2018).

3. Owusu, P.A.; Asumadu-Sarkodie, S. A review of renewable energy sources, sustainability issues and climate change mitigation. Cogent Eng. 2016, 3, 1167990. [CrossRef]

4. Lewis, N.S.; Nocera, D.G. Powering the planet: Chemical challenges in solar energy utilization. Proc. Natl. Acad. Sci. USA 2006, 103, 15729-15735. [CrossRef] [PubMed]

5. Dupeyrat, P.; Ménézo, C.; Fortuin, S. Study of the thermal and electrical performances of PVT solar hot water system. Energy Build. 2014, 68, 751-755. [CrossRef]

6. Chen, M.; He, Y.; Zhu, J.; Wen, D. Investigating the collector efficiency of silver nanofluids based direct absorption solar collectors. Appl.Energ. 2016, 181, 65-74. [CrossRef]

7. Kalogirou, S.A.; Karellas, S.; Braimakis, K.; Stanciu, C.; Badescu, V. Exergy analysis of solar thermal collectors and processes. Prog. Energy Combust. Sci. 2016, 56, 106-137. [CrossRef]

8. Minardi, J.E.; Chuang, H.N. Performance of a "black" liquid flat-plate solar collector. Sol. Energy 1975, 17, 179-183. [CrossRef]

9. Choi, S.U.; Eastman, J.A. Enhancing Thermal Conductivity of Fluids with Nanoparticles; Argonne National Lab.: Cass Avenue, IL, USA, 1995.

10. Sokhansefat, T.; Kasaeian, A.; Kowsary, F. Heat transfer enhancement in parabolic trough collector tube using Al2O3/synthetic oil nanofluid. Renew. Sustain. Energy Rev. 2014, 33, 636-644. [CrossRef]

11. Wang, X.-Q.; Mujumdar, A.S. Heat transfer characteristics of nanofluids: A review. Int. J. Thermal Sci. 2007, 46, 1-19. [CrossRef]

12. Hordy, N.; Rabilloud, D.; Meunier, J.L.; Coulombe, S. High temperature and long-term stability of carbon nanotube nanofluids for direct absorption solar thermal collectors. Sol. Energy. 2014, 105, 82-90. [CrossRef]

13. Kalogirou, S.A. Solar thermal collectors and applications. Prog. Energy Combust. Sci. 2004, 3, $231-295$. [CrossRef]

14. Newman, M.D. Flat plate solar collector. U. S. patent 5,653,222, 5 August 1997.

15. Qiu, S.; Ruth, M.; Ghosh, S. Evacuated tube collectors: A notable driver behind the solar water heater industry in China. Renew. Sustain. Energy Rev. 2015, 47, 580-588. [CrossRef]

16. Ng, K.M.; Adam, N.M.; Azmi, B.Z.; Wahab, M.A.; Sulaiman, M.Y. Field study of solar bowl under Malaysian tropical climate. WSEAS Trans. Environ. Dev. 2012, 8, 48-59.

17. Jain, D.; Tewari, P. Performance of indirect through pass natural convective solar crop dryer with phase change thermal energy storage. Renew. Energy 2015, 80, 244-250. [CrossRef]

18. Croitoru, C.V.; Nastase, I.; Bode, F.I.; Meslem, A. Thermodynamic investigation on an innovative unglazed transpired solar collector. Sol. Energy 2016, 131, 21-29. [CrossRef]

19. Laboratory, N.R.E. Assessment of Parabolic trough and Power Tower Solar Technology Cost and Performance Forecasts; DIANE Publishing: Collingdale, PA, USA, 2003; Volume 550.

20. Häberle, A. Linear Fresnel Collectors. In Solar Energy; Springer: Berlin, Germany, 2013; pp. 72-78.

21. Wu, S.Y.; Xiao, L.; Cao, Y.; Li, Y.R. Convection heat loss from cavity receiver in parabolic dish solar thermal power system: A review. Sol. Energy 2010, 84, 1342-1355. [CrossRef]

22. Zhu, G. Development of an analytical optical method for linear Fresnel collectors. Sol. Energy 2013, 94, 240-252. [CrossRef]

23. Parabolic Trough Reflector for Solar Thermal System. Available online: http:/ /www.alternative-energytutorials.com/solar-hot-water/parabolic-trough-reflector.html (accessed on 29 December 2018).

24. Qu, M.; Archer, D.H.; Yin, H. A linear parabolic trough solar collector performance model. In Proceedings of the ASME 2007 Energy Sustainability Conference, Long Beach, CA, USA, 27-30 July 2007; American Society of Mechanical Engineers: New York, NY, USA, 2007.

25. Leemrani, Z.; Marrakchi, S.; Asselman, H.; Asselman, A. The study of the performance of a parabolic trough collector in the region of north-west of Morocco. Procedia Manuf. 2018, 22, 780-787. [CrossRef]

26. Fernández-García, A.; Zarza, E.; Valenzuela, L.; Pérez, M. Parabolic-trough solar collectors and their applications. Renew. Sustain. Energy Rev. 2010, 14, 1695-1721. [CrossRef] 
27. Sharma, K.; Kundan, L. Nanofluid Based Concentrating Parabolic Solar Collector (NBCPSC): A New Alternative. Int. J. Res. Mech. Eng. Technol. 2014, 2, 2249-5762.

28. Khullar, V.; Tyagi, H. Application of nanofluids as the working fluid in concentrating parabolic solar collectors. In Proceedings of the 37th National \& 4th International Conference on Fluid Mechanics \& Fluid Power, Chennai, India, 16-18 December 2010.

29. Otanicar, T.P.; Phelan, P.E.; Prasher, R.S.; Rosengarten, G.; Taylor, R.A. Nanofluid-based direct absorption solar collector. J. Renew. Sustain. Energy 2010, 2, 033102. [CrossRef]

30. Khullar, V.; Tyagi, H.; Phelan, P.E.; Otanicar, T.P.; Singh, H.; Taylor, R.A. Solar energy harvesting using nanofluids-based concentrating solar collector. J. Nanotechnol. Eng. Med. 2012, 3, 031003. [CrossRef]

31. Saidur, R.; Meng, T.C.; Said, Z.; Hasanuzzaman, M.; Kamyar, A. Evaluation of the effect of nanofluid-based absorbers on direct solar collector. Int. J. Heat Mass Transf. 2012, 55, 5899-5907. [CrossRef]

32. Verma, V.; Kundan, L. Thermal performance evaluation of a direct absorption flat plate solar collector (DASC) using Al2O3-H2O based nanofluids. ISOR J. Mech. Civ. Eng. 2013, 6, 2320-3344. [CrossRef]

33. Parvin, S.; Nasrin, R.; Alim, M. Heat transfer and entropy generation through nanofluid filled direct absorption solar collector. Int. J. Heat Mass Transf. 2014, 71, 386-395. [CrossRef]

34. Verma, S.K.; Tiwari, A.K. Progress of nanofluid application in solar collectors: A review. Energy Convers. Manag. 2015, 100, 324-346. [CrossRef]

35. Nagarajan, P.K.; Subramani, J.; Suyambazhahan, S.; Sathyamurthy, R. Nanofluids for solar collector applications: A review. Energy Procedia 2014, 61, 2416-2434. [CrossRef]

36. Sandeep, H.; Arunachala, U. Solar parabolic trough collectors: A review on heat transfer augmentation techniques. Renew. Sustain. Energy Rev. 2017, 69, 1218-1231. [CrossRef]

37. Bellos, E.; Tzivanidis, C.; Tsimpoukis, D. Enhancing the performance of parabolic trough collectors using nanofluids and turbulators. Renew. Sustain. Energy Rev. 2018, 91, 358-375. [CrossRef]

38. Bellos, E.; Tzivanidis, C. Thermal efficiency enhancement of nanofluid-based parabolic trough collectors. J. Thermal Anal. Calorim. 2018, 1-12. [CrossRef]

39. Bellos, E.; Tzivanidis, C. A review of concentrating solar thermal collectors with and without nanofluids. J. Thermal Anal. Calorim. 2018, 1-23. [CrossRef]

40. Kandwal, S.; Lal, K.G. An Experimental Investigation into Nanofluids (Cuo-H2o \&Cuo-Ethylene Glycol) Based Parabolic Solar Collector. Master's Thesis, Thapar institute, Patiala, India, 2015.

41. Kandwal, S.; Lal, K.G. An Experimental Investigation into the Performance of a Nanofluid Based Concentrating Parabolic Solar Collector (NCPSC). Ph.D. Thesis, Thapar institute, Patiala, India.

42. Coccia, G.; Di Nicola, G.; Colla, L.; Fedele, L.; Scattolini, M. Adoption of nanofluids in low-enthalpy parabolic trough solar collectors: Numerical simulation of the yearly yield. Energy Convers. Manag. 2016, 118, 306-319. [CrossRef]

43. Bellos, E.; Tzivanidis, C. Parametric analysis and optimization of an Organic Rankine Cycle with nanofluid based solar parabolic trough collectors. Renew. Energy 2017, 114, 1376-1393. [CrossRef]

44. Kasaeian, A.; Daneshazarian, R.; Rezaei, R.; Pourfayaz, F.; Kasaeian, G. Experimental investigation on the thermal behavior of nanofluid direct absorption in a trough collector. J. Clean. Prod. 2017, 158, 276-284. [CrossRef]

45. Kasaeian, A.; Daviran, S.; Azarian, R.D.; Rashidi, A. Performance evaluation and nanofluid using capability study of a solar parabolic trough collector. Energy Convers. Manag. 2015, 89, 368-375. [CrossRef]

46. Siva Reddy, E.; Reddy, R.M.; Reddy, K.K. Experimental Study on Thermal Efficiency of Parabolic Trough Collector (PTC) Using $\mathrm{Al}_{2} \mathrm{O}_{3} / \mathrm{H}_{2} \mathrm{O}$ Nanofluid. In Applied Mechanics and Materials; Trans Tech Publ.: Zurich, Switzerland, 2015.

47. Chaudhari, K.S.; Walke, P.V.; Wankhede, U.S.; Shelke, R.S. An Experimental Investigation of a Nanofluid $\left(\mathrm{Al}_{2} \mathrm{O}_{3}+\mathrm{H}_{2} \mathrm{O}\right)$ Based Parabolic Trough Solar Collectors. Br. J. Appl. Sci. Technol. 2015, 9, 551-557. [CrossRef]

48. Menbari, A.; Alemrajabi, A.A.; Rezaei, A. Heat transfer analysis and the effect of $\mathrm{CuO} /$ Water nanofluid on direct absorption concentrating solar collector. Appl. Thermal Eng. 2016, 104, 176-183. [CrossRef]

49. Subramani, J.; Nagarajan, P.K.; Wongwises, S.; El-Agouz, S.A.; Sathyamurthy, R. Experimental study on the thermal performance and heat transfer characteristics of solar parabolic trough collector using $\mathrm{Al}_{2} \mathrm{O}_{3}$ nanofluids. Environ. Prog. Sustain. Energy 2017, 37, 1149-1159. [CrossRef]

50. Sekhar, T.V.; Prakash, R.; Nandan, G.; Muthuraman, M. Performance enhancement of a renewable thermal energy collector using metallic oxide nanofluids. Micro Nano Lett. 2017, 13, 248-251. [CrossRef] 
51. Rehan, M.A.; Ali, M.; Sheikh, N.A.; Khalil, M.S.; Chaudhary, G.Q.; ur Rashid, T.; Shehryar, M. Experimental performance analysis of low concentration ratio solar parabolic trough collectors with nanofluids in winter conditions. Renew. Energy 2018, 118, 742-751. [CrossRef]

52. Subramani, J.; Nagarajan, P.K.; Mahian, O.; Sathyamurthy, R. Efficiency and heat transfer improvements in a parabolic trough solar collector using $\mathrm{TiO}_{2}$ nanofluids under turbulent flow regime. Renew. Energy 2018, 119, 19-31. [CrossRef]

53. Marefati, M.; Mehrpooya, M.; Shafii, M.B. Optical and thermal analysis of a parabolic trough solar collector for production of thermal energy in different climates in Iran with comparison between the conventional nanofluids. J. Clean. Prod. 2018, 175, 294-313. [CrossRef]

54. Okonkwo, E.C.; Abid, M.; Ratlamwala, T.A. Numerical analysis of heat transfer enhancement in a parabolic trough collector based on geometry modifications and working fluid usage. J. Sol. Energy Eng. 2018, 140, 051009. [CrossRef]

55. Alsaady, M.; Fu, R.; Yan, Y.; Liu, Z.; Wu, S.; Boukhanouf, R. An experimental investigation on the effect of ferrofluids on the efficiency of novel parabolic trough solar collector under laminar flow conditions. Heat Transf. Eng. 2018. [CrossRef]

56. De los Rios, M.S.B.; Rivera-Solorio, C.I.; García-Cuéllar, A.J. Thermal performance of a parabolic trough linear collector using $\mathrm{Al}_{2} \mathrm{O}_{3} / \mathrm{H}_{2} \mathrm{O}$ nanofluids. Renew. Energy 2018, 122, 665-673. [CrossRef]

57. Okonkwo, E.C.; Essien, E.A.; Abid, M.; Kavaz, D.; Ratlamwala, T.A. Thermal performance analysis of a parabolic trough collector using water-based green-synthesized nanofluids. Sol. Energy 2018, 170, 658-670. [CrossRef]

58. Mwesigye, A.; Yılmaz, İ.H.; Meyer, J.P. Numerical analysis of the thermal and thermodynamic performance of a parabolic trough solar collector using SWCNTs-Therminol ${ }^{\circledR}$ VP-1 nanofluid. Renew. Energy 2018, 119, 844-862. [CrossRef]

59. Mwesigye, A.; Meyer, J.P. Optimal thermal and thermodynamic performance of a solar parabolic trough receiver with different nanofluids and at different concentration ratios. Appl. Energy 2017, 193, 393-413. [CrossRef]

60. Mwesigye, A.; Huan, Z.; Meyer, J.P. Thermal performance and entropy generation analysis of a high concentration ratio parabolic trough solar collector with Cu-Therminol ${ }^{\circledR}$ VP-1 nanofluid. Energy Convers. Manag. 2016, 120, 449-465. [CrossRef]

61. Mwesigye, A.; Huan, Z.; Meyer, J.P. Thermal Performance of a Receiver Tube for a High Concentration Ratio Parabolic trough System and Potential for Improved Performance with Syltherm800-CuO Nanofluid. In Proceedings of the ASME 2015 International Mechanical Engineering Congress and Exposition, Houston, TX, USA, 13-19 November 2015; American Society of Mechanical Engineers: New York, NY, USA, 2015.

62. Bellos, E.; Tzivanidis, C. Optimization of a solar-driven trigeneration system with nanofluid-based parabolic trough collectors. Energies 2017, 10, 848. [CrossRef]

63. Kasaeian, A.B.; Sokhansefat, T.; Abbaspour, M.J.; Sokhansefat, M. Numerical study of heat transfer enhancement by using $\mathrm{Al}_{2} \mathrm{O}_{3}$ /synthetic oil nanofluid in a parabolic trough collector tube. World Acad. Sci. Eng. Technol. 2012, 69, 1154-1159.

64. Zadeh, P.M.; Sokhansefat, T.; Kasaeian, A.B.; Kowsary, F.; Akbarzadeh, A. Hybrid optimization algorithm for thermal analysis in a solar parabolic trough collector based on nanofluid. Energy 2015, 82, 857-864. [CrossRef]

65. Mwesigye, A.; Huan, Z.; Meyer, J.P. Thermodynamic optimisation of the performance of a parabolic trough receiver using synthetic oil- $\mathrm{Al}_{2} \mathrm{O}_{3}$ nanofluid. Appl. Energy 2015, 156, 398-412. [CrossRef]

66. Mwesigye, A.; Huan, Z. Thermodynamic analysis and optimization of fully developed turbulent forced convection in a circular tube with water- $\mathrm{Al}_{2} \mathrm{O}_{3}$ nanofluid. Int. J. Heat Mass Transf. 2015, 89, 694-706. [CrossRef]

67. Basbous, N.; Taqi, M.; Belouaggadia, N. Numerical study of a parabolic trough collector using a nanofluid. Asian J. Curr. Eng. Math. 2015, 4, 40-44.

68. Bellos, E.; Tzivanidis, C.; Antonopoulos, K.A.; Gkinis, G. Thermal enhancement of solar parabolic trough collectors by using nanofluids and converging-diverging absorber tube. Renew. Energy 2016, 94, $213-222$. [CrossRef]

69. Wang, Y.; Xu, J.; Liu, Q.; Chen, Y.; Liu, H. Performance analysis of a parabolic trough solar collector using $\mathrm{Al}_{2} \mathrm{O}_{3}$ /synthetic oil nanofluid. Appl. Thermal Eng. 2016, 107, 469-478. [CrossRef] 
70. Kaloudis, E.; Papanicolaou, E.; Belessiotis, V. Numerical simulations of a parabolic trough solar collector with nanofluid using a two-phase model. Renew. Energy 2016, 97, 218-229. [CrossRef]

71. Benabderrahmane, A.; Benazza, A.; Aminallah, M.; Laouedj, S. Heat transfer behaviors in parabolic trough solar collector tube with compound technique. Int. J. Sci. Res. Eng. Technol. (IJSRET) 2016, 5, 410-417.

72. Amina, B.; Miloud, A.; Samir, L.; Abdelylah, B.; Solano, J.P. Heat transfer enhancement in a parabolic trough solar receiver using longitudinal fins and nanofluids. J. Thermal Sci. 2016, 25, 410-417. [CrossRef]

73. Ghasemi, S.E.; Ranjbar, A.A. Effect of using nanofluids on efficiency of parabolic trough collectors in solar thermal electric power plants. Int. J. Hydrog. Energy 2017, 42, 21626-21634. [CrossRef]

74. Basbous, N.; Taqi, M.; Janan, M.A. Thermal performances analysis of a parabolic trough solar collector using different nanofluids. In Proceedings of the 2016 International Renewable and Sustainable Energy Conference (IRSEC), Marrakech, Morocco, 14-17 November 2016.

75. Toghyani, S.; Baniasadi, E.; Afshari, E. Thermodynamic analysis and optimization of an integrated Rankine power cycle and nano-fluid based parabolic trough solar collector. Energy Convers. Manag. 2016, 121, 93-104. [CrossRef]

76. Nayak, Y.K.; Sharma, S.P.; Sinha, U.K.; Kumar, P.; Kumar, N. A Novel Solution Methodology for the Optimization of Thermal Analysis in the Solar Parabolic Trough Collector. Ind. J. Sci. Technol. 2016, 9. [CrossRef]

77. Ferraro, V.; Settino, J.; Cucumo, M.A.; Kaliakatsos, D. Parabolic trough system operating with nanofluids: Comparison with the conventional working fluids and influence on the system performance. Energy Procedia 2016, 101, 782-789. [CrossRef]

78. Khakrah, H.; Shamloo, A.; Hannani, S.K. Determination of Parabolic Trough Solar Collector Efficiency Using Nanofluid: A Comprehensive Numerical Study. J. Sol. Energy Eng. 2017, 139, 051006. [CrossRef]

79. Bellos, E.; Tzivanidis, C. Parametric investigation of nanofluids utilization in parabolic trough collectors. Thermal Sci. Eng. Prog. 2017, 2, 71-79. [CrossRef]

80. Bellos, E.; Tzivanidis, C.; Tsimpoukis, D. Thermal, hydraulic and exergetic evaluation of a parabolic trough collector operating with thermal oil and molten salt based nanofluids. Energy Convers. Manag. 2018, 156, 388-402. [CrossRef]

81. Allouhi, A.; Amine, M.B.; Saidur, R.; Kousksou, T.; Jamil, A. Energy and exergy analyses of a parabolic trough collector operated with nanofluids for medium and high temperature applications. Energy Convers. Manag. 2018, 155, 201-217. [CrossRef]

82. Bellos, E.; Tzivanidis, C. Thermal analysis of parabolic trough collector operating with mono and hybrid nanofluids. Sustain. Energy Technol. Assess. 2018, 26, 105-115.

83. Kasaiean, A.; Sameti, M.; Daneshazarian, R.; Noori, Z.; Adamian, A.; Ming, T. Heat transfer network for a parabolic trough collector as a heat collecting element using nanofluid. Renew. Energy 2018, 123, 439-449. [CrossRef]

84. Bilal, F.; Arunachala, U.; Sandeep, H. Experimental validation of energy parameters in parabolic trough collector with plain absorber and analysis of heat transfer enhancement techniques. J. Phys. Conf. Ser. 2018, 953, 012030. [CrossRef]

85. Hatami, M.; Geng, J.; Jing, D. Enhanced Efficiency in Concentrated Parabolic Solar Collector (CPSC) with a Porous Absorber Tube Filled with Metal Nanoparticle Suspension. Green Energy Environ. 2018, 3, 129-137. [CrossRef]

86. Minea, A.A.; El-Maghlany, W.M. Influence of hybrid nanofluids on the performance of parabolic trough collectors in solar thermal systems: Recent findings and numerical comparison. Renew. Energy 2018, 120, 350-364. [CrossRef]

87. Ghasemi, S.E.; Ranjbar, A.A. Thermal performance analysis of solar parabolic trough collector using nanofluid as working fluid: A CFD modelling study. J. Mol. Liquids 2016, 222, 159-166. [CrossRef]

(C) 2019 by the authors. Licensee MDPI, Basel, Switzerland. This article is an open access article distributed under the terms and conditions of the Creative Commons Attribution (CC BY) license (http://creativecommons.org/licenses/by/4.0/). 